\title{
Hydro-morphometric characterization and prioritization of sub-watersheds for land and water resource management using fuzzy analytical hierarchical process (FAHP): a case study of upper Rihand watershed of Chhattisgarh State, India
}

\author{
Milan Ghosh $^{1,2} \cdot$ Dipti Gope $^{1}$
}

Received: 19 August 2020 / Accepted: 10 December 2020 / Published online: 14 January 2021

(c) The Author(s) 2021

\begin{abstract}
Rihand reservoir is continuously experiencing siltation due to erosion in upper basin; thus study of morphometric-based prioritization of sub-watershed has become prerequisite for implementation of measures for conservation of soil and water resource. In present study an attempted has been made to analyze characterization and prioritization of sub-watersheds in upper basin of Rihand watershed based on hydro-morphometric parameters, in an environment of Geographical Information System (GIS), with the help of Multicriteria Decision Making through Fuzzy Analytical Hierarchy Process (FAHP) techniques in order to identify critical sub-watersheds for conservation and management of soil and water resource. The morphometric characterization has been done through measurement of linear, areal and relief aspect of over seven sub-watersheds using SOI topographical sheet and SRTM data with the help of Q GIS 3.10 and White box software. In the purpose prioritization of sub-watersheds FAHP method has been implemented through assigning fuzzy membership function to each of 15 morphometric parameters by deriving their relationships with erosional hazard and criterion weight has been obtained using Saaty's (Fundamentals of decision making and priority theory with analytical hierarchical process, RWS Publications University of Pittsburgh, Pittusburgh, 1980) proposed method. Based on prioritization approach the entire sub-watershed has divided into 3 vulnerable zones, i.e., high, medium and low. This study reveals that about $29 \%$ area of the watershed is falls under high vulnerable zone as they obtained high priority value and required immediate measures. In addition, ideal locations for measure structure to prevent soil erosion and maximize infiltration has been proposed which will be useful to the decision maker for land and water resource conservation, management, and sustainable agricultural development.
\end{abstract}

Keywords Fuzzy analytical hierarchy process (FAHP) · Erosional hazard · Geographical information system (GIS) . Hydro-morphometric parameter $\cdot$ Multicriteria decision making $(\mathrm{MCDM}) \cdot$ Rihand watershed

\section{Abbreviations \\ AHP Analytical hierarchy process \\ DEM Digital elevation model \\ GIS Geographical information system}

Supplementary information The online version of this article (https://doi.org/10.1007/s13201-020-01340-x) contains

supplementary material, which is available to authorized users.

Milan Ghosh

ghosh.milan543@gmail.com

1 Department of Geography, University of Kalyani, Kalyani, India

2 Ex JRF of DBT Sponsored Project, Tripura University, Tripura, India
FAHP Fuzzy analytical hierarchy process

LU/LC Land use/land cover

MCDM Multicriteria decision making

SOI Survey of India

MSL Mean sea level

TFN Triangular fuzzy number

SRTM Shuttle Radar Topography Mission

SW Sub-watershed

CI Consistency index

$C_{c} \quad$ Compactness constant

$R_{\mathrm{c}} \quad$ Circularity ratio

$D_{\mathrm{d}} \quad$ Drainage density

$I_{\mathrm{f}} \quad$ Infiltration no

$L_{\text {sm }} \quad$ Mean stream length

$R_{\mathrm{bm}} \quad$ Mean bifurcation ratio 


$\begin{array}{ll}F_{\mathrm{s}} & \text { Stream frequency } \\ R_{\mathrm{t}} & \text { Drainage texture ratio } \\ R_{\mathrm{e}} & \text { Elongation ratio } \\ O_{1} & \text { Length of overland flow } \\ R_{\mathrm{r}} & \text { Relative relief } \\ R_{h} & \text { Relief ratio } \\ R_{\mathrm{n}} & \text { Ruggedness no. } \\ \mathrm{HI} & \text { Hypsometric integral } \\ S_{\mathrm{g}} & \text { Stream gradient } \\ R_{\mathrm{f}} & \text { Form factor }\end{array}$

\section{Introduction}

Land and water are two vital resources for all living organism on the earth surface; human beings also required these to ensure food security, economic development and social progress. Amount of fresh water and fertile soil on the earth is limited and rapid rate of population growth increasing pressure on these non-renewal natural resources all over the world. As a result soil and water resources are deteriorating due to human activities such as deforestation, land-use changes, agricultural activity, industrialization, road construction, and river bed mining, etc. This environmental issue in turn gives birth of several hydro-morphological hazards, e.g., soil erosion, flood, drought, reduction in land capability, etc., within watershed boundary. Therefore, a sustainable management plan for conservation soil and water resources is required to fulfill demand of increasing population for food and other needs. Watershed deterioration has become a common environmental issue all over the world including India. A watershed is a natural hydrological unit that generates surface runoff from the rainfall which flows through channel, streams, river, lakes or oceans (Prabhakar et al. 2019; Chopra et al. 2005). Natural resources of a watershed may be deteriorated due to increase in surface runoff which leads soil erosion and which in turns decrease productivity of the land and groundwater level. Thus, water resources management decisions depend on the timings of runoff characteristics of a watershed (Dinpashoh et al. 2019). The timing of runoff generally depends on surface hydrology, morphometric configuration, lithological characteristics and climatic condition of a basin. Morphometric configuration of a watershed is not only predominantly control the timing of surface runoff but also it is the reflection of lithological, geological, hydrological and climatic condition; therefore, morphometry analysis can play a vital role in finding out the characteristics of watershed (Prabhakar et al. 2019; Tripathi et al. 2003). Morphometry is the measurement and mathematical analysis of the configuration of the earth's surface, shape and dimension of its landforms (Rahaman et al. 2015; Obi Reddy et al. 2002; Agarwal 1998). Horton (1932) was the pioneer followed by Miller
(1953); Schumm (1956); Strahler (1957, 1964), Hadley (1961); Leopold (1964), and Morisawa (1985) have laid the foundation of quantitative analysis of basin morphometry. Many researchers (Maurya et al. 2016; Pandey et al. 2012; Srivastava and Sharma 2012; Kiran and Srivastava 2012; Thakur et al. 2012; Ratnam et al. 2005) have been suggested that morphometric analysis of sub-watershed can be applied for Selection of suitable location of check dams, trenches, grooves, farm ponds, spillways, etc., constructed for soil and water conservation, and (Sangma and Guru 2020; Mohd and Sajjad 2014; Biswas et al. 1999) can be applied as a single factor without considering the soil characteristics for prioritization of sub-watershed. Morphometric parameters are divided into three aspects, i.e., linear aspects, areal aspects, and relief aspects, to analyze the shape and dimension of the earth surface (Sangma and Guru 2020; Putty 2007; Nag and Chakraborty 2003a, b; Bats and Jackson 1987; Clarke 1966).Use of Remote Sensing GIS techniques in morphometric analysis of watershed has been widely used across the world by many researchers (Fang 2020; Gautam 2020; Islam and Deb Barman 2020; Sinha et al. 2019; Adhami 2019; Jafarzadegan and Merwade 2017; Roy and Sahu 2016a, b; Das et al. 2016; Sharma and Tiwari 2014; Koshak and Dawod 2011; Manu and Anirudhan 2008; Kouli et al. 2007; Vijith and Satheesh 2006; Grohmann 2004; Svetlitchnyi et al. 2003; Lapena and Martz 1996) and suggested that as a proficient tools for morphometric characterization of subwatersheds (Farhan and Anaba 2016; Rahaman et al. 2015; Aher et al. 2013; Kanth and Hassan 2012; Sreedevi et al. 2009; Grohmann 2004; Singh 1994).

Prioritization of watershed is a crucial part of watershed management as in contains some sensitive information regarding surface hydrology and able to answer some crucial questions such as where to construct check dam, reservoir, embankment, etc., to minimize soil erosion, flooding, bank erosion and maximize infiltration. Traditional approach in watershed prioritization from basin morphometry is based on calculating compound parameter value, as averages of individual parameter values (Gopinath 2016). But recently a large number of studies have been undertaken for prioritizing sub-catchments with consideration of different factors by multicriteria decision-making models (MCDM) (Chitsaz and Malekian 2016; Rahaman et al. 2015; Ahmadisharaf et al. 2015; Kim et al. 2013; Chung et al. 2011). Some researcher have used (Gopinath 2016; Chowdary et al. 2013) Analytic network process (ANP) while a large number of researcher (Jain and Ramsankaran 2019; Balasubramani et al. 2019; Meshram et al. 2019; Rahmati et al. 2016; Jaiswal et al. 2014) suggested analytical hierarchical process (AHP). Many researchers (Chang 1996; Boender et al. 1989; Van Laarhoven and Pedrycz 1983) have preferred fuzzy AHP over AHP as it provides more adequate portrayal 
of basic leadership and used (Hembram and Saha 2020; Meshram 2019; Jaiswal et al. 2015) analytical hierarchical process (FAHP)as a reliable tools for prioritization of sub-watershed.

Rihand river is mainly a rain feed river and an important tributary of river Son, originated from Matiranga hills, in the region south west of the Mainpat plateau, which is about 1,100 meters above mean sea level. Due to steep slope and undulated topography along with human interference, the upper part of the watershed is continuously subjected to erosion and as a result eroded materials were deposited in Rihand Reservoir. In present study an approach has been made to compute prioritization index for sub-watersheds of Rihand watershed based on morphometry parameters with application of analytical hierarchical process (APH) to identifying and ranking suitable micro-watersheds for soil and water conservation and proper utilization in a sustainable way. The study combined with geology and geomorphology studies, helps to construct a primary hydrological diagnosis (Kumar et al. 2017; Hungr 2000).

\section{Materials and methods}

\section{Study area}

Rihand River is an important right bank tributary of river Son originated from Matiranga hills in the region south west of the Mainpat plateau flows toward north through Chhattisgarh, Madhya Pradesh Uttar Pradesh and joins to River Son near Sonbhadra district of Uttar Pradesh. The main tributaries of Rihand river are the Mahan, the Morana (Morni), the Geur, the Gagar, the Gobri, the Piparkachar, the Ramdia and the Galphulla. The study area comprise in upper part of Rihand river which is lies between geographic $22^{\circ} 30^{\prime} \mathrm{N}$ to $24^{\circ} 00^{\prime} \mathrm{N}$ latitudes and $82^{\circ} 15^{\prime} \mathrm{E}$ to $83^{\circ} 45^{\prime} \mathrm{E}$ longitudes (Fig. 1) and a total area of about $10,210 \mathrm{~km}^{2}$. The maximum and minimum elevation encountered in the watershed about $277 \mathrm{~m}$ and $1200 \mathrm{~m}$ above mean sea level (MSL). Southern parts of the basin covered by dense forest while agricultural activity is dominate in the northern part. This river is mainly rain feed river and the maximum rainfall is received during the month of July to October. Geologically, the Rihand River watershed is part of Vindhyan Supergroup, composed

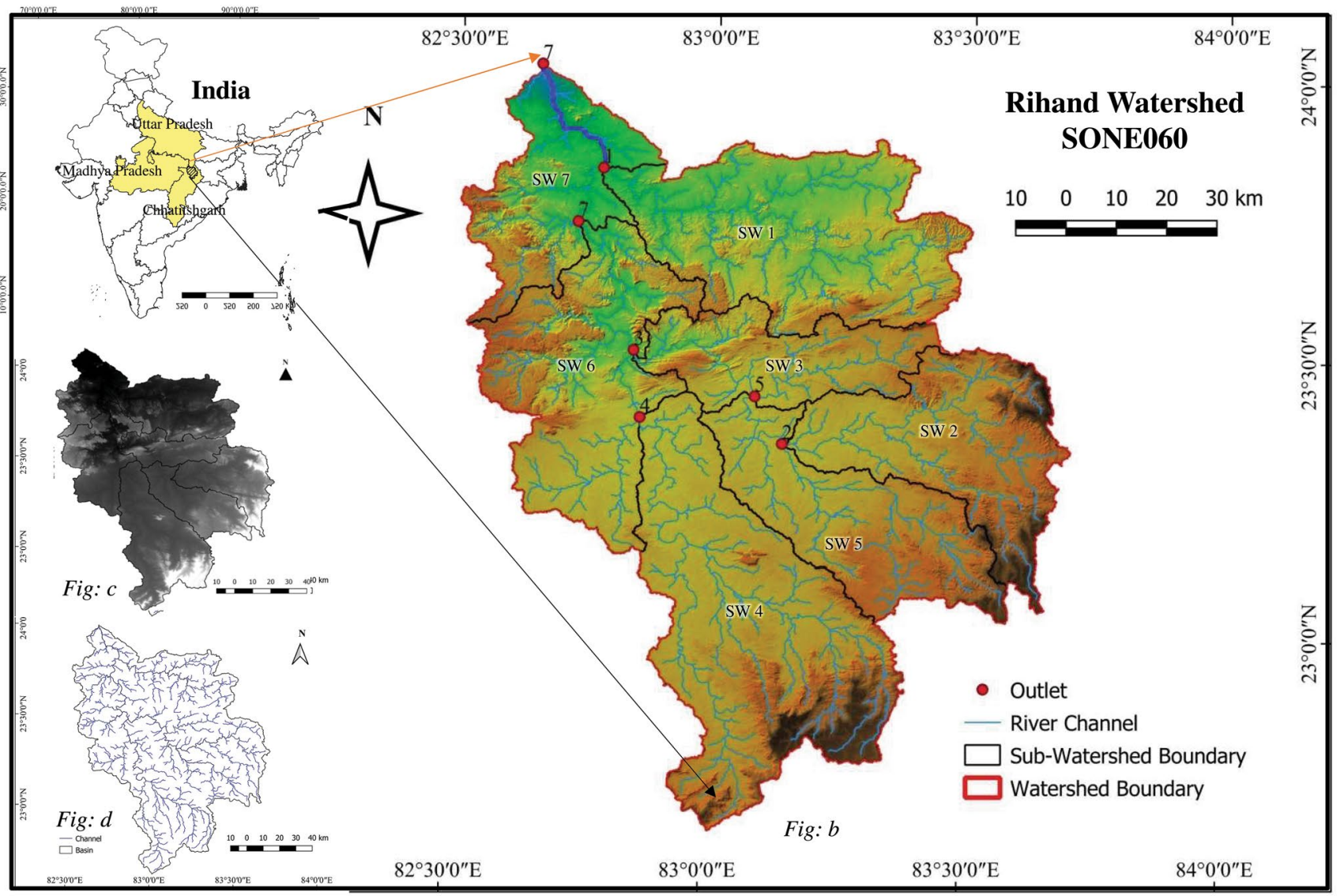

Fig. 1 a, b Location of Rihand watersheds $\mathbf{c}$ DEM; $\mathbf{d}$ channel 
of low dipping formations of sandstone, shale and carbonate, with a few conglomerate and volcanic beds, separated by a major regional and several local unconformities (Kumar et al. 2017; Bhattacharyya 1996). The entire area occupied by 3 group of rock, i.e., (1) Mahakoshal Group made of phyllite with quartzite, andalusite mica schist, limestone, acid intrusive, metabasic rocks, cherty quartzite, slate, marble and tuff, (2) Dudhi group overlie the Mahakoshal Group and consist of medium- to fine-grained diorite, gray granodiorite, epidotized pink tourmaline gneiss, leucocratic granite, and enclaves of metamorphites, amphibolites, granite gneiss, migmatite and metasedimentaries and (3) Damuda Group consist of coarse ferruginous sandstone intercalated with coal seams and green shale (Kumar et al. 2017). Rihand dam also known as Govind Ballabh Pant Sagar has been constructed over this river in the year of 1962 at Pipri in Sonbhadra District in Uttar Pradesh, the north most point of the study area.

\section{Data and software}

For the delineation of watershed boundary Survey of India (SOI) topographical map no64I/9, 63 L/16, 64 M1, 63P/4, 64 I/13 and 63 L/12 has been used. For better accuracy and avoid data gap or any distortion Digital Elevation has been used along with SOI topographical sheet. A number of researchers suggested that Shuttle Radar Topography Mission Digital Elevation (SRTM-DEM) is much better than ASTER DEM as its vertical and horizontal accuracy is greater and able to provide more accurate data to morphometric analyses (Prakash et al. 2019; Patel et al. 2016; Kaushik and Ghosh 2015; Forkuor and Maathuis 2012; Farr et al. 2007). Therefore, Shuttle Radar Topography Mission (SRTM) Digital Elevation data with a spatial resolution of $90 \mathrm{~m}$ (downloaded from the https://www.srtm.csi.cgiar.org) has been used in this study. Missing data in SRTM-DEM are filled by interpolation techniques and sink fill algorithm applied as preprocessing of DEM for minimizing errors (Prakash et al. 2019). Drainage map and basin map were prepared from SOI topographical sheet. Extraction of channel network and delineation of sub-watersheds has been done by processing SRTM data of the study area in White Tool box. After delineating 7 sub-watersheds the morphometric parameter (length of the individual stream, basin area and perimeter of the basin) was extracted in the Q GIS-3.12 platform and used for the morphometric analysis (linear, areal and relief aspects).

\section{Morphometric parameters}

In the study of the watershed prioritization is important to understand hydrological behaviors along with the morphology and relief of the watershed; thus selection of the appropriate parameters largely influences the result of the study. In these regards 15 morphometric parameters (Table 1) including the linear, areal and relief aspects which are closely associated with soil and water resource degradation has been considered for prioritization of Rihand sub-watersheds.

\section{Application of fuzzy analytical hierarchical process (FAHP)}

Various methods such as quantitative, fuzzy logic, statistic methods, ANP and AHP have been used widely by several researches to prioritize sub-watersheds. In present study Fuzzy Analytical Hierarchical Process (FAHP) has been used to prioritize sub-watersheds based on morphometric analysis. AHP is one of the most popular multicriteria decision-making tools which relies on a hierarchical structure to explain the decision problem and does a pair-wise comparison between criteria to arrive at the weights used in the prioritization ranking (Gopinath et al. 2016; Triantaphyllou and Mann 1995). In spite of popularity of AHP, this method is often criticized for its inability to adequately handle the inherent uncertainty and imprecision associated with the mapping of the decision maker's perception to exact numbers (Rahaman, et al. 2015). In fuzzy AHP a crisp number $(1,2,3)$ is replaced by fuzzy number $\{(1,1,1)$, $(2,3,4),(3,4,5) \ldots$.$\} to remove uncertainty and vagueness in$ expert's decision making. Therefore, AHP has been used through fuzzy operations for prioritization of sub-watersheds in Rihand basin.

\section{A brief of fuzzy set and triangular fuzzy number (TFN)}

Fuzzy set theory was introduced by (Zadeh 1965), deals with uncertainty and source of vagueness and has been utilized for incorporating imprecise data into the decision framework (Brahma 2018). A fuzzy number is a fuzzy set in which the membership function satisfy condition of normality and of convexity and a triangular fuzzy number (TFN) is a set of 3 crisp numeric value can be expressed as $\mu=[l, m, u]$ where $[l<m<u]$ and in case of $[l=m=u]$ it can't be consider as a fuzzy number. In this study the relative important of each pair of criterion has been expressed through TFN using numerical value ranges between 0 and 9 as suggested by Saaty (1980) and stated in (Mishra et al. 2018; Jaiswal et al. 2014).

\section{Construction of fuzzy pair-wise comparison matrix}

The first task of the fuzzy AHP method is to decide on the relative importance of each pair of factors in the same hierarchy (Chang 1996). The triangular fuzzy number used for pair-wise comparison matrix, the fuzzy evolution matrix 
Table 1 Morphometric parameters

\begin{tabular}{|c|c|c|c|}
\hline \multicolumn{2}{|c|}{ Morphometric parameters } & \multirow{2}{*}{$\begin{array}{l}\text { Computation } \\
\text { Hierarchical rank }\end{array}$} & \multirow{2}{*}{$\begin{array}{l}\text { References } \\
\text { Strahler (1964) }\end{array}$} \\
\hline Linear Aspect & Stream order & & \\
\hline & Stream length $(L \mu)$ & Length of the stream & Horton (1945) \\
\hline & Mean stream length $\left(L_{\mathrm{sm}}\right)$ & $\begin{array}{l}L_{\mathrm{sm}}=L \mu / N \mu \\
(N \mu=\text { total no. of stream segments of a given order })\end{array}$ & Strahler $((1964)$ \\
\hline & Stream length ratio $\left(R_{1}\right)$ & $\begin{array}{l}\mathrm{RL}=L_{u} / L_{u}-1 \\
\left(L_{u}=\text { total stream length of a given order; and } L_{\mathrm{u}}-1=\text { total stream length }\right. \\
\text { of its next lower order })\end{array}$ & Horton (1945) \\
\hline & Bifurcation ratio $\left(R_{\mathrm{b}}\right)$ & $\begin{array}{l}R_{\mathrm{b}}=N \mu / N \mu+1 \\
(N \mu=\text { total no. of stream segments of a given order; and } N \mu+1=\text { no. of } \\
\text { segments of the next higher order })\end{array}$ & Schumm (1956) \\
\hline & Mean bifurcation ratio $\left(R_{\mathrm{bm}}\right)$ & $R_{\mathrm{bm}}=$ average of bifurcation ratios of all orders & Strahler (1957) \\
\hline \multirow[t]{8}{*}{ Areal Aspect } & Drainage density $(D)$ & $\begin{array}{l}D=L_{u} / A \\
\left(L_{u}=\text { total stream length of all orders; and } A=\text { area of the basin }\right)\end{array}$ & Horton (1932) \\
\hline & Stream frequency $\left(F_{\mathrm{s}}\right)$ & $\begin{array}{l}F_{\mathrm{s}}=N_{u} / A \\
\left(N_{u}=\text { total no. of streams of all orders; and } A=\text { area of the basin }\right)\end{array}$ & Horton (1932) \\
\hline & Drainage texture ratio $\left(R_{\mathrm{t}}\right)$ & $\begin{array}{l}\mathrm{R}_{t}=\mathrm{Nu} / \mathrm{P} \\
\left(N_{u}=\text { total no. of streams of all orders; and } P=\text { perimeter of the basin) }\right.\end{array}$ & Horton (1945) \\
\hline & Infiltration no. $\left(I_{\mathrm{f}}\right)$ & $\begin{array}{l}I_{\mathrm{f}}=R_{\mathrm{t}} \times F_{\mathrm{s}} \\
\left(R_{\mathrm{t}}=\text { drainage texture ratio; and } F_{\mathrm{s}}=\text { drainage frequency }\right)\end{array}$ & Faniran (1968) \\
\hline & Length of overland flow $\left(L_{g}\right)$ & $\begin{array}{l}L_{g}=1 / D \times 2 \\
(D=\text { drainage density })\end{array}$ & Horton (1945) \\
\hline & Circulatory ratio $\left(R_{\mathrm{c}}\right)$ & $\begin{array}{l}R_{\mathrm{c}}=4 \pi \times A / P 2 \\
(\pi=3.14 ; A=\text { area of the basin; and } P 2=\text { square of the perimeter })\end{array}$ & Miller (1953) \\
\hline & Form factor $\left(R_{\mathrm{f}}\right)$ & $\begin{array}{l}R_{\mathrm{f}}=A / L_{\mathrm{b}}^{2} \\
\left(A=\text { area of the basin; and } L_{\mathrm{b}}^{2}=\text { square of basin length }\right)\end{array}$ & Horton (1932) \\
\hline & Elongation ratio $\left(R_{\mathrm{e}}\right)$ & $\begin{array}{l}R_{\mathrm{e}}=\sqrt[2]{\left(\frac{A}{\pi}\right)} / L_{\mathrm{b}} \\
\left(A=\text { area of the basin } \pi=3.14 ; \text { and } L_{\mathrm{b}}=\text { basin length }\right)\end{array}$ & Schumm (1956) \\
\hline \multirow[t]{4}{*}{ Relief aspect } & Relative relief $\left(R_{\mathrm{r}}\right)$ & Maximum elevation minus minimum elevation of the basin & Strahler (1952) \\
\hline & Relief ratio $R_{h}$ & $\begin{array}{l}R_{h}=H / L_{\mathrm{b}} \\
\left(H=\text { total relief (relative relief) of the basin in kilometers; and } L_{\mathrm{b}}=\text { basin }\right. \\
\text { length })\end{array}$ & Schumm (1956) \\
\hline & Ruggedness no. $\left(R_{\mathrm{n}}\right)$ & $\begin{array}{l}R_{\mathrm{n}}=D \times T_{\mathrm{r}} / 1000 \\
\left(D=\text { drainage density; and } T_{\mathrm{r}}=\text { total relief }\right)\end{array}$ & Strahler (1964) \\
\hline & $\begin{array}{l}\text { Hypsometric integral } \\
\text { Stream gradient }\left(S_{\mathrm{g}}\right)\end{array}$ & $\begin{array}{l}\mathrm{HI}=\frac{\text { mean elevation-minimum elevation }}{\text { maximum elevation-minimum elevation }} \\
S_{\mathrm{g}}=\frac{E_{1}-E_{2}}{L}=\frac{\Delta H}{L L} \\
E_{1}-E_{2}^{L}=\text { difference in the elevation between two points on the stream } \\
\quad(\Delta H) \mathrm{SL}=\text { Stream length }(\Delta L)\end{array}$ & $\begin{array}{l}\text { Strahler }(1952,1964) \\
\text { Hack (1957) }\end{array}$ \\
\hline
\end{tabular}

( $\left.\tilde{A}=\tilde{a}_{i j}\right)$ of $n$ criteria is constructed using Eq. 1 has given as follows

$\tilde{A}=\left[\begin{array}{cccc}1 & \tilde{a}_{12} & \cdots & \tilde{a}_{1 n} \\ \tilde{a}_{21} & 1 & \cdots & \tilde{a}_{2 n} \\ \cdots & \cdots & \ddots & \cdots \\ \tilde{a}_{n 1} & \tilde{a}_{n 2} & \cdots & 1\end{array}\right]$

where $\tilde{a}_{i j}$ is a fuzzy triangular number, $\tilde{a}_{i j}=\left(l_{i j}, m_{i j}, u_{i j}\right)$, and $\tilde{a}_{i j}^{-1}=\frac{1}{\tilde{a}_{i j}}$. For each TFN, $\tilde{a}_{i j}$ or $M=1, m$, its membership function $\mu_{\vec{a}}(x)$ or $\mu_{m}(x)$ is a continuous mapping of real number $-\propto \leq x \leq \propto$ to the close interval $[0,1]$ and can be define by equation below

$\mu_{\tilde{a}}(x)= \begin{cases}\frac{(x-1)}{(m-1)^{\prime}} & l \leq x \leq m \\ \frac{(u-x)}{(u-m)^{\prime}} & m \leq x \leq u . \\ 0, & \text { otherwise }\end{cases}$

The operations on TFNs can be additional, multiplication and inverse. Suppose M1 and M2 are two TFNs where $M_{1}=\left(l_{1}, m_{1}, u_{1}\right)$, and $M_{2}=\left(l_{2}, m_{2}, u_{2}\right)$, then, 
Additional $M_{1} \oplus M_{2}=\left(l_{1}+l_{2}, m_{1}+m_{2}, u_{1}+u_{2}\right)$

Multiplication $M_{1} \otimes M_{2}=\left(l_{1} \times l_{2}, m_{1} \times m_{2}, u_{1} \times u_{2}\right)$

Inverse $M_{1}^{-1}=\left(l_{1}, m_{1}, u_{1}\right)^{-1}=\frac{1}{u_{1}}, \frac{1}{m_{1}}, \frac{1}{l_{1}}$.

After computing pair-wise comparison matrix from all decision makers, these matrices can were aggregated by using the fuzzy geometric mean method (Buckley 1985) using following formula.

$l_{i}=\left[\prod_{j=1}^{n} l i j\right]^{1 / n} \& l=\left[\sum_{i=1}^{n} l_{i}\right]$

$m_{i}\left[\prod_{j=1}^{n} m_{i j}\right]^{1 / n} \& m=\left[\sum_{i=1}^{n} m_{i}\right]$

$u_{i}\left[\prod_{j=1}^{n} u_{i j}\right]^{1 / n} \& u=\left[\sum_{i=1}^{n} u_{i}\right]$

The fuzzy membership function describing the weights of different parameters is defined by the following equation.

$\bar{x}_{i}=\left[\frac{l_{i}}{u}, \frac{m_{i}}{m}, \frac{u_{i}}{l}\right]$

The center of area (COA) method is employed to de-fuzzify the membership function, which gives crisp weights for all the parameters using following formula.

$x_{i}=\frac{l_{i}+m_{i}+u_{i}}{3}$

In fuzzy AHP, pair-wise matrix is computed by decision maker itself based on his/her personal knowledge and ability hence consistency checking is to eliminate any subjectivity in decision-making process. Thus, consistency has been measured using consistency Ratio (CR) using following formula

$\mathrm{CR}=\frac{\mathrm{CI}}{\mathrm{RI}}$

where $\mathrm{CI}$ is the consistency index which depends on size of the matrix and can be estimated using the following equation

$\mathrm{CI}=\frac{\lambda_{\max }-N}{N-1}$

where $\lambda_{\max }$ is the principal eigenvalue (Han and Tsay 1998; Malczewski 1999) that can be computed approximately by calculating the product of the pair-wise comparison matrix and the weight vectors, de-fuzzifying this matrix and adding all elements of the resulting vector of the resulting vector (Mishra et al. 2018). RI is the random consistency index a unitless predefined value which depends on number of criterion $(n)$ that used to generate a matrix as given in Table 1. If the value of CR is less than 0.1 then the decision is considered as consistent.

The values of morphometric parameters may vary in the diverse ranges and therefore, there is a need to bring down those on same scale. Normalization approach to restrict the variation in the range from 0 to 1 is applied using Eq. (9) as follows;

$W_{i j}=\frac{\frac{P_{i j}}{P_{i \max }}}{\sum_{i=1}^{n} p}$ or $\frac{\frac{P_{\text {min }}}{P_{i j}}}{\sum_{i=1}^{n} p}$

where $W_{i j}$ is the normalized value of $i$ th morphometric parameter $(P)$ of $j$ th watershed; $P_{i \min _{i}}$ and $P_{i \max }$ are the original upper and lower bound for $i$ th morphometric parameter $(P) . P_{i j}$ is the original value of $i$ th morphometric parameter $(P)$ of $j$ th watershed. Here first equation is applicable for beneficial parameters; which are positively correlated with degradation and second one is for inversely correlated parameters. After this, final priority $\left(F_{j}\right)$ of a watershed in the present FAHP-based MCDS is computed by summing the product of normalized value of all alternative and its corresponding criterion weights obtained from FAHP analysis, as follows:

$F_{j}=\sum_{i=1}^{n} x_{i} \times w_{i j}$.

Based on the final priorities of all sub-watersheds in Rihand watershed, they are categorized in different priority classes for conservation measures. Entire methodology of sub-watershed prioritization is shown in Fig. 2.

\section{Results}

\section{Morphometric characterizations}

\section{Stream order}

The first step in the drainage basin analysis is the order designation (Fig. 5a) following a system (Strahler 1964), i.e., assigning the value of first order to every finger-tip stream and promote their order to next order (e.g., first order to second order, second order to third order, third order to fourth and so on) if two channels of the same order meet and order remains unchanged in case of two channel of different orders meet. As per Horton's low of stream numbers, number of 


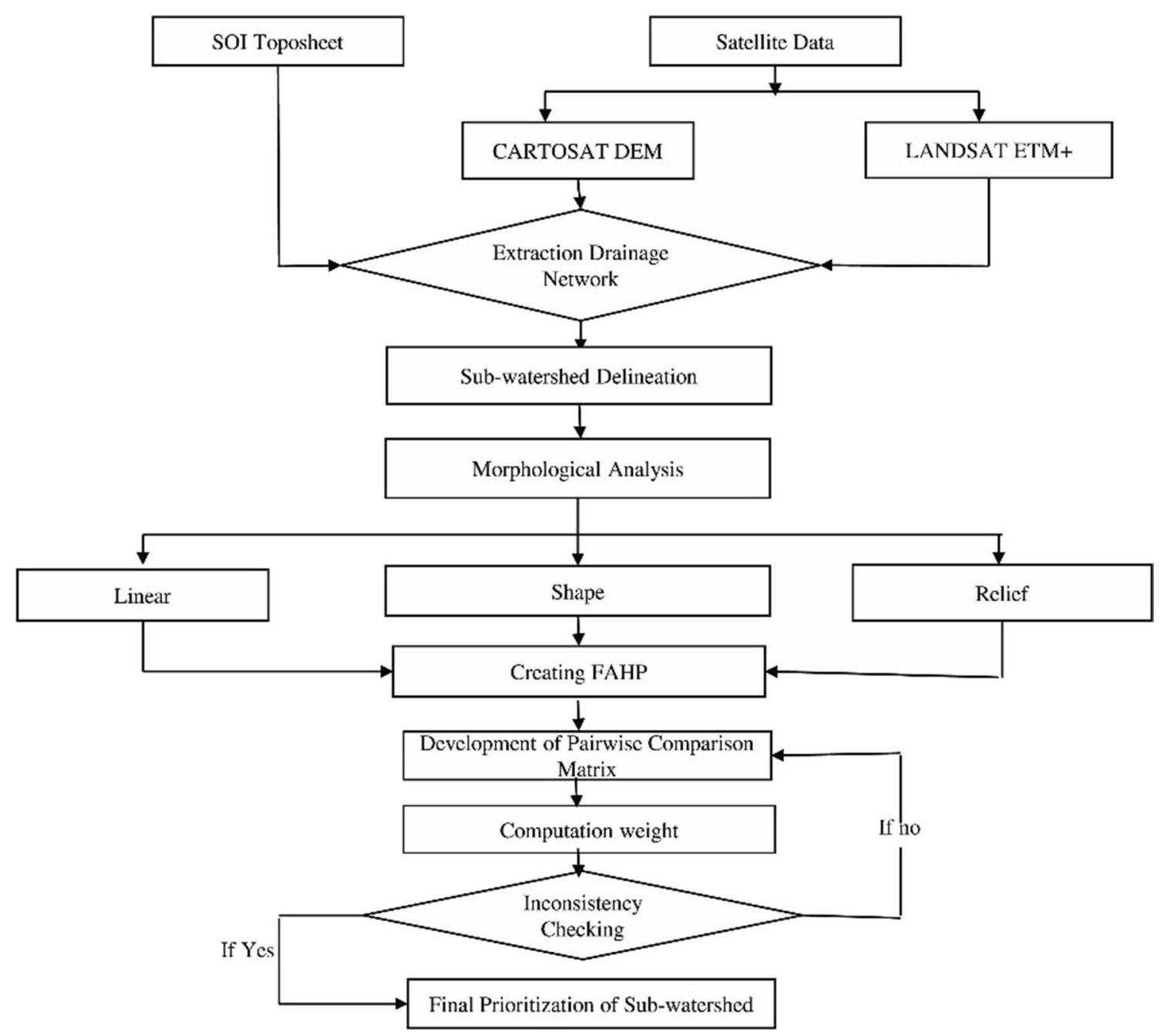

Fig. 2 Flowchart of methodology for sub-watersheds prioritization

stream segment decrease with increasing order as shown in Fig. 3. Table 2 indicates that there are seven sub-watersheds, out of these one sub-watershed (SW-7) is seventh ordered and 2 sub-watersheds (SW-2 and SW-4) are fifth ordered and rests of the sub-watersheds are sixth ordered.

\section{Bifurcation ratio $\left(R_{\mathrm{b}}\right)$}

Horton introduced the term 'bifurcation ratio $\left(R_{\mathrm{b}}\right)$ ' to express the ratio of the number of any stream of any given order to the number in the next lower order (Leopold 1964). According to Horton (1945, p. 290) the value of bifurcation ratio may range between 2 and 4 while Stralher (1964) suggested that In natural drainage system has a value of bifurcation ratio 3.0-5.0 in which geologic structures do not distort the drainage pattern. The value of bifurcation ration generally indicates tectonic and hydrological properties of a basin. Higher the value of bifurcation ratio means more chances of occurrence flood hazard, soil erosion and increase in overland flow on the other hand lower the value of bifurcation ratio means well developed drainage system, minimum surface flow, and no soil erosion and flood would be take place. In present study, the value of the mean $R_{b}$ lies between 2.634 and 4.915 which are shown in Table 2 .

\section{Stream length $(L \mu)$}

The law of stream lengths expresses the average length of streams of a given order in terms of stream order, average length of streams of the 1 st order, and the stream length ratio (Horton 1945). As per Horton's second law, the total length of the stream decreased with increasing in stream order that's means 1st order stream occupy maximum length (Fig. 4). Sub-watershed wise stream length and total stream length for each order are expressed in (Table 3). 


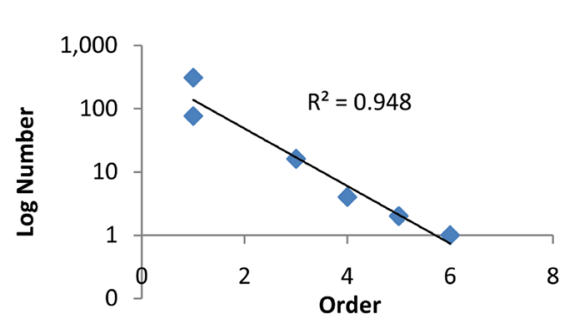

SW 2

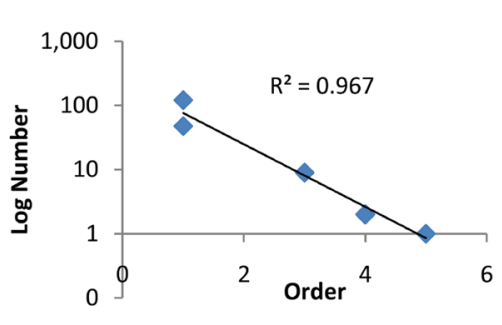

SW 2

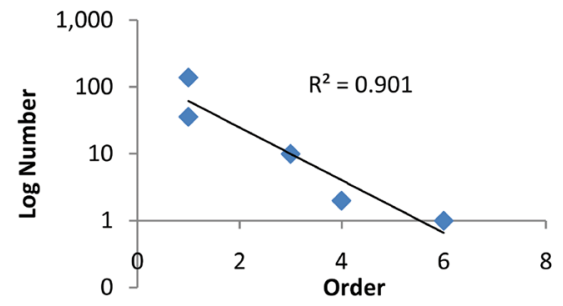

SW 3

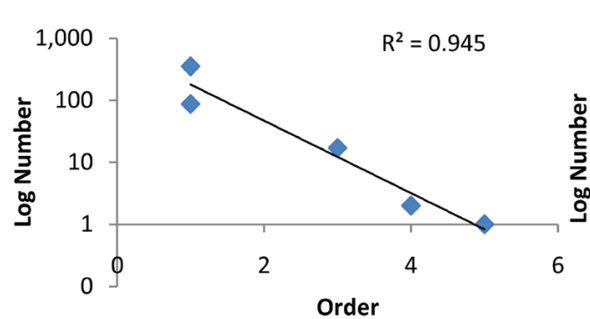

SW 4

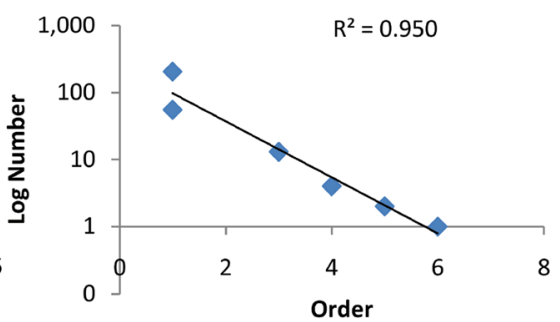

SW 6

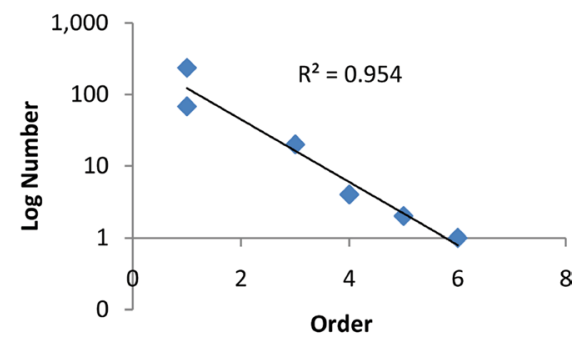

SW 6

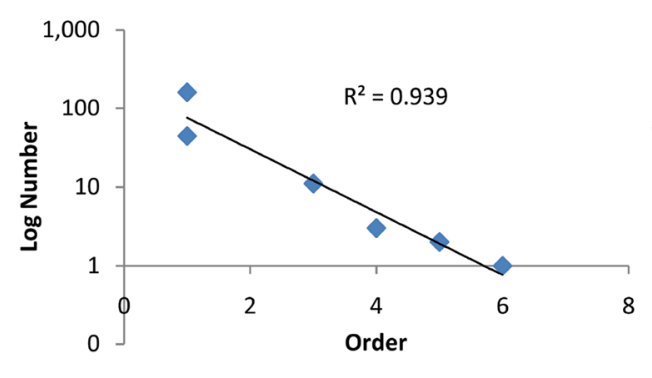

SW 7

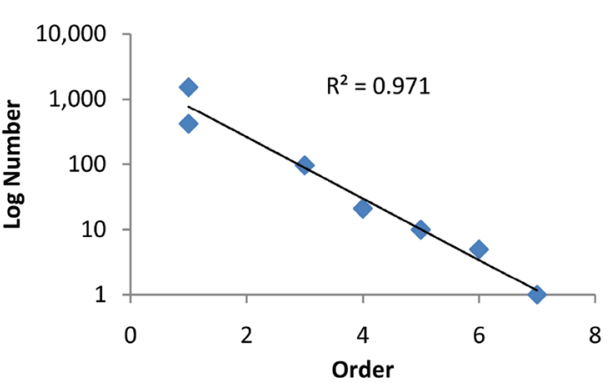

Rihand Watershed

Fig. 3 Horton's law of stream number ( $x$ axis—stream order $(u) ; y$ axis- $\log$ total number of stream)

Table 2 Sub-watershed wise stream Numbers and bifurcation ratio $\left(R_{\mathrm{b}}\right)$

\begin{tabular}{|c|c|c|c|c|c|c|c|c|c|c|c|c|c|c|c|}
\hline \multirow[t]{2}{*}{ Sub-watershed } & \multicolumn{7}{|c|}{ Order wise number of stream } & \multirow[t]{2}{*}{ Total } & \multicolumn{6}{|c|}{ Order wise $R_{\mathrm{b}}$} & \multirow[t]{2}{*}{ Mean $R_{\mathrm{b}}$} \\
\hline & I & II & III & IV & V & VI & VII & & I & II & III & IV & V & VI & \\
\hline SW1 & 307 & 76 & 16 & 4 & 2 & 1 & 0 & 406 & 4.039 & 4.75 & 4.00 & 2.00 & 2 & - & 3.357 \\
\hline SW2 & 122 & 48 & 9 & 2 & 1 & 0 & 0 & 182 & 2.541 & 5.333 & 4.50 & 2.00 & - & - & 3.593 \\
\hline SW3 & 139 & 36 & 10 & 2 & 0 & 1 & 0 & 188 & 3.861 & 3.60 & 5.00 & - & - & - & 3.115 \\
\hline SW4 & 352 & 87 & 17 & 2 & 1 & 0 & 0 & 459 & 4.045 & 5.117 & 8.50 & 2.00 & - & - & 4.915 \\
\hline SW5 & 204 & 55 & 13 & 4 & 2 & 1 & 0 & 279 & 3.709 & 4.230 & 3.25 & 2.00 & 2 & - & 3.037 \\
\hline SW6 & 235 & 68 & 20 & 4 & 2 & 1 & 0 & 330 & 3.455 & 3.40 & 5.00 & 2.00 & 2 & - & 3.171 \\
\hline SW7 & 160 & 44 & 11 & 3 & 2 & 1 & 1 & 222 & 3.636 & 4.00 & 3.667 & 1.50 & 2 & 1 & 2.634 \\
\hline Total & 1519 & 414 & 96 & 21 & 10 & 5 & 1 & 2066 & 3.67 & 4.31 & 4.57 & 2.1 & 2 & 5 & 3.608 \\
\hline
\end{tabular}

\section{Mean stream length $\left(L_{\mathrm{sm}}\right)$}

According to Strahler (1964), the stream length is a characteristic property related to drainage network components of drainage basins. Generally, the longest mean length of the stream associate with the highest stream order (Fig. 4).
Stream order-wise means length of the stream for each watershed has been calculated by dividing the total stream length of a order by total number of stream segment under that particular order (Table 3 ). Sw-4 recorded highest mean stream length which indicates greater erosion and less infiltration. 

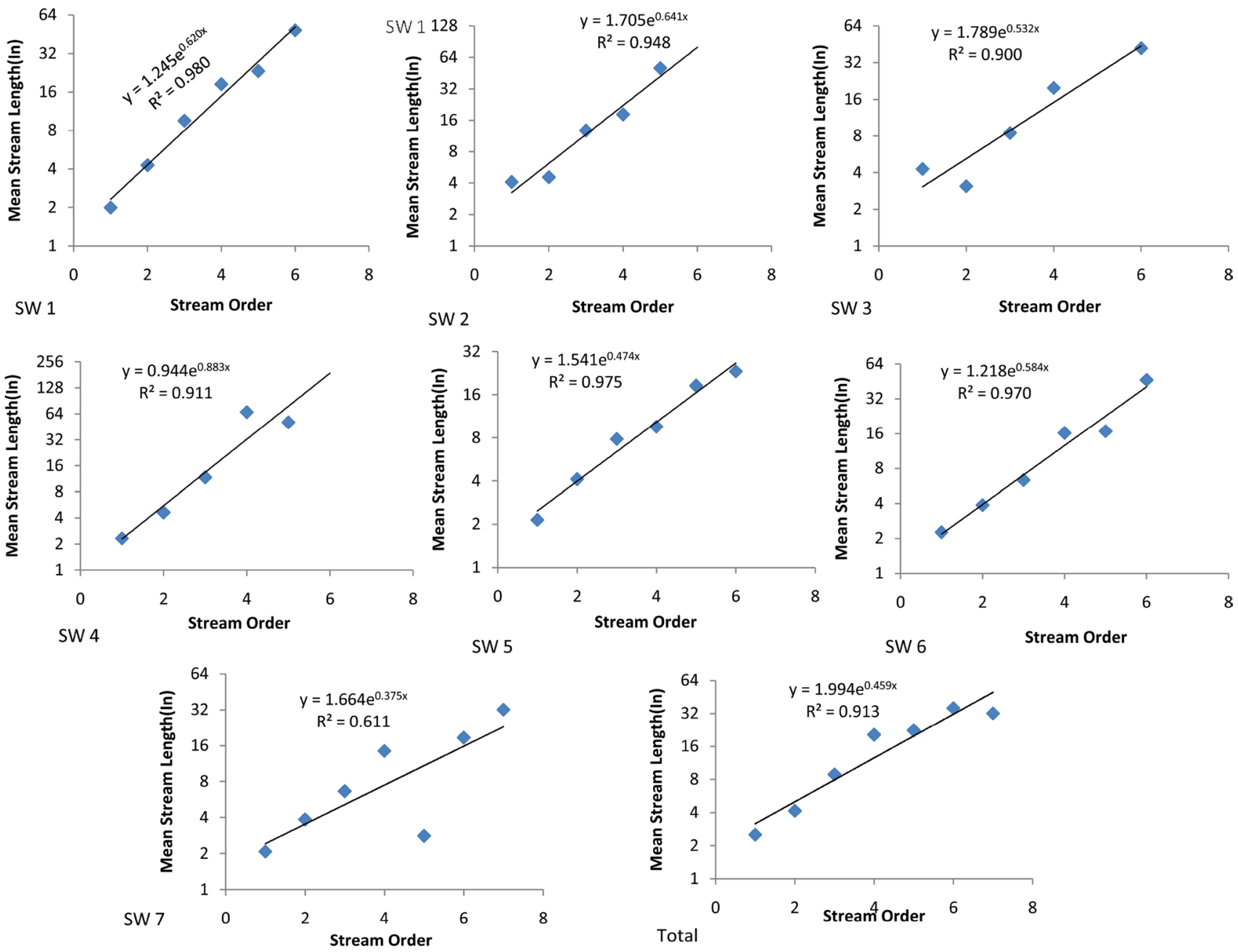

Fig. 4 Horton's law of stream length ( $x$ axis—stream order $(u) ; y$ axis—log mean stream length

Table 3 Total stream length $(L \mu)$ and mean stream length $\left(L_{\mathrm{sm}}\right)$

\begin{tabular}{|c|c|c|c|c|c|c|c|c|c|c|c|c|c|c|c|c|}
\hline \multirow[t]{2}{*}{ Sub-watershed } & \multicolumn{7}{|c|}{ Stream order wise total length of stream $(L \mu)$} & \multirow[t]{2}{*}{ Total } & \multicolumn{7}{|c|}{ Stream order wise mean length of stream $\left(L_{\mathrm{sm}}\right)$} & \multirow[t]{2}{*}{ Mean } \\
\hline & I & II & III & IV & $\mathrm{V}$ & VI & VII & & I & II & III & IV & $\mathrm{V}$ & VI & VII & \\
\hline SW1 & 611.93 & 324.63 & 152.77 & 73.79 & 46.7 & 48.54 & & 1258.38 & 1.99 & 4.27 & 9.54 & 18.44 & 23.35 & 48.54 & & 17.69 \\
\hline SW2 & 498.54 & 218.19 & 114.46 & 36.38 & 50.39 & & & 917.97 & 4.08 & 4.54 & 12.71 & 18.19 & 50.39 & & & 17.98 \\
\hline SW3 & 592.55 & 110.98 & 84.33 & 39.64 & & 41.9 & & 869.38 & 4.26 & 3.08 & 8.43 & 19.82 & 0 & 41.9 & & 15.5 \\
\hline SW4 & 819 & 402.89 & 199.12 & 133.56 & 50.85 & & & 1605.43 & 2.32 & 4.63 & 11.71 & 66.78 & 50.85 & & & 27.26 \\
\hline SW5 & 438.39 & 226.52 & 101.98 & 38.29 & 37.01 & 23.26 & & 865.45 & 2.14 & 4.11 & 7.84 & 9.57 & 18.5 & 23.26 & & 10.9 \\
\hline SW6 & 531.62 & 263.09 & 126.82 & 64.69 & 33.48 & 46.56 & & 1066.28 & 2.26 & 3.86 & 6.34 & 16.17 & 16.74 & 46.56 & & 15.32 \\
\hline SW7 & 332.43 & 169.62 & 73.11 & 43.27 & 5.61 & 18.64 & 32.08 & 674.79 & 2.07 & 3.85 & 6.64 & 14.42 & 2.8 & 18.64 & 32.08 & 11.5 \\
\hline
\end{tabular}

\section{Length of overland flow $\left(L_{0}\right)$}

Length of overland flow denoted by ' $L_{\mathrm{O}}$ ' is used to describe the length of flow of water over the ground before it becomes concentrated in definite stream channels (Horton, 1945). It is important morphometric variables, can independently control rate of infiltration and soil loss. In Rihand watershed, the length of overland flow ranges from 0.48 to 0.76 (Table 4) 
Table 4 Value of morphometric analysis

\begin{tabular}{lccccccc}
\hline $\begin{array}{l}\text { Sub-watersheds } \\
\text { parameters }\end{array}$ & SW1 & SW2 & SW3 & SW4 & SW5 & SW6 & SW7 \\
\hline$L_{\mathrm{sm}}$ & 17.69 & 17.99 & 12.91 & 27.26 & 10.9 & 15.32 & 11.5 \\
$D_{\mathrm{d}}$ & 0.68 & 0.69 & 1.03 & 0.67 & 0.7 & 0.66 & 0.71 \\
$D_{\mathrm{f}}$ & 0.219 & 0.136 & 0.224 & 0.191 & 0.23 & 0.206 & 0.234 \\
$R_{\mathrm{t}}$ & 1.12 & 0.55 & 0.77 & 1.09 & 1.04 & 1 & 0.92 \\
$R_{\mathrm{bm}}$ & 3.357 & 3.593 & 3.115 & 4.915 & 3.037 & 3.171 & 2.634 \\
$C_{\mathrm{c}}$ & 2.4 & 2.58 & 2.41 & 2.45 & 2.18 & 2.34 & 2.21 \\
$R^{f}$ & 0.33 & 0.41 & 0.24 & 0.33 & 0.24 & 0.37 & 0.36 \\
$R_{\mathrm{e}}$ & 0.64 & 0.72 & 0.55 & 0.65 & 0.54 & 0.69 & 0.68 \\
$R_{\mathrm{c}}$ & 0.18 & 0.15 & 0.17 & 0.16 & 0.21 & 0.28 & 0.2 \\
$O_{\mathrm{l}}$ & 0.73 & 0.73 & 0.48 & 0.76 & 0.71 & 0.75 & 0.7 \\
$I_{\mathrm{f}}$ & 0.25 & 0.07 & 0.12 & 0.24 & 0.18 & 0.19 & 0.14 \\
$S_{\mathrm{g}}$ & 1.87 & 8.46 & 2.11 & 5.52 & 3.08 & 5.89 & 4.41 \\
$\mathrm{HI}$ & 0.214 & 0.4823 & 0.304 & 0.241 & 0.22 & 0.347 & 0.471 \\
$R_{n}$ & 0.302 & 0.54 & 0.44 & 0.4 & 0.37 & 0.47 & 0.35 \\
$R_{\mathrm{r}}$ & 443.5 & 774.9 & 426 & 633 & 510.8 & 706.05 & 585 \\
$R_{h}$ & 0.0059 & 0.0136 & 0.0071 & 0.0074 & 0.0071 & 0.0102 & 0.0094 \\
\hline
\end{tabular}

\section{Infiltration number $\left(I_{\mathrm{f}}\right)$}

Infiltration Number is an important morphometric parameter which helps to predict permeability of surface of the watershed and generally depends on relief, slope, lithology and vegetation cover. Greater values of ' $I_{\mathrm{f}}$ ' indicates impermeable surface and resistance to soil loss and contrary the lower values point toward erosive nature of the watersheds (Hembram et al. 2020). In the present study, sub-watershed wise infiltration numbers are computed. SWS-2 has recorded lowest value of $I_{\mathrm{f}}(0.07)$ which indicates higher risk for erosion, and SWS-4 has the highest value with maximum infiltration and minimum erosion (Table 4).

\section{Drainage density $\left(D_{\mathrm{d}}\right)$}

Drainage density $\left(D_{\mathrm{d}}\right)$ is an important areal morphometric parameter and can be defined as total length of the stream per unit drainage area and reflects the degree of drainage development within a basin (Horton 1945). Horton (1932) suggested that if the length of the stream measured from a map then map scale should be sufficiently large enough (U. S. Geological Survey topographic maps) to show the entire permanent stream. Generally, its values depend upon the function of climate, lithology and structure characteristics of the drainage basins and higher values of drainage density reflect higher dissected drainage watershed and rapid response with respect to rainfall events and for lower values vice versa (Prabhakar et al. 2019). It is also important that the drainage density is the reciprocal of the constant channel maintenance; that means basin with lower drainage density has higher constant channel maintenance and vice versa
(Morisawa 1985). The $D_{\mathrm{d}}$ of sub-watersheds ranges from 0.66 to $1.03 \mathrm{~km} / \mathrm{km}^{2}$ which is shown in Table 4 and Fig. 5 b.

\section{Stream frequency $\left(F_{\mathrm{S}}\right)$}

Stream frequency or Drainage frequency $\left(F_{\mathrm{S}}\right)$ is the total number of stream of all orders per unit area of the watershed (Horton 1932). Stream frequency of a drainage basin generally depends upon lithology, relief, and climatic conditions of the watersheds and has a close correlation with drainage density. Higher the value of Stream frequency indicates high degree of surface runoff and high probability of soil erosion and occurrence of flood. The stream frequency value of Rihand River Basin is less than other river basins present in Central India (Rai et al. 2017, Kumar et al. 2017; Singh et al. 2013). In this study, value of stream frequency ranges from 0.14 to 0.23 as shown in Table 4 . SW-5 and SW-7 has recorded maximum drainage frequency as produced maximum surface runoff.

\section{Texture ratio $\left(R_{\mathrm{t}}\right)$}

Cotton (1935) and others have used the term "texture" to express composition of a drainage net as related both to drainage density and stream frequency (Horton, 1945). It can be define as the length of the stream segments of the all orders per unit perimeter of the basin. Smith (1950) has developed texture ratio to describe the degree of closeness or proximity of one stream segment to another (Leopold et al. 1964). Texture ratio of a drainage basin depends on its lithology, relief, amount of slope and climatic conditions and its value reflect degree rate of infiltration and soil erosion. 


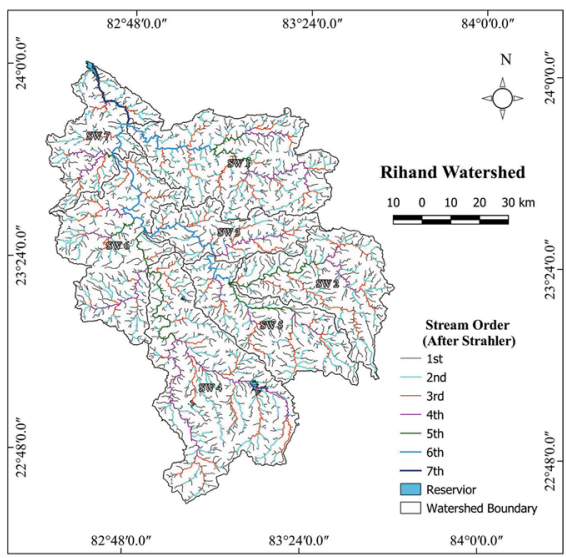

[1]

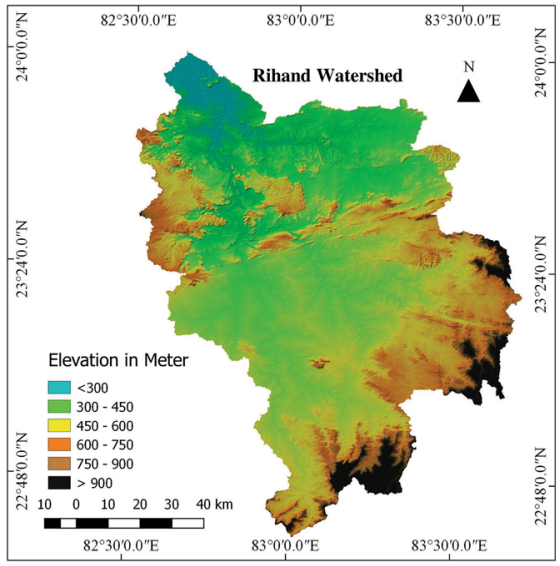

[4]

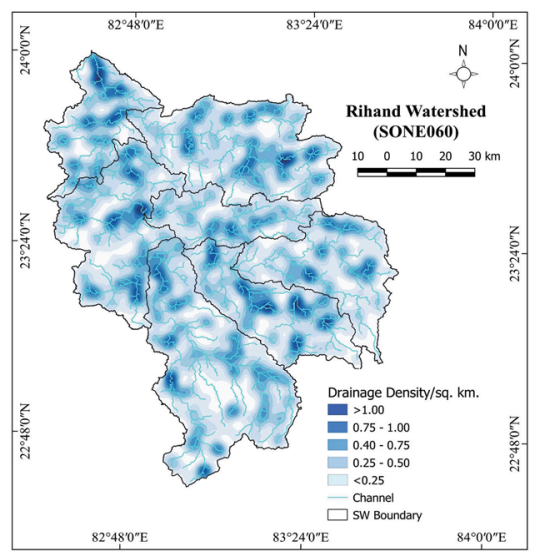

[2]

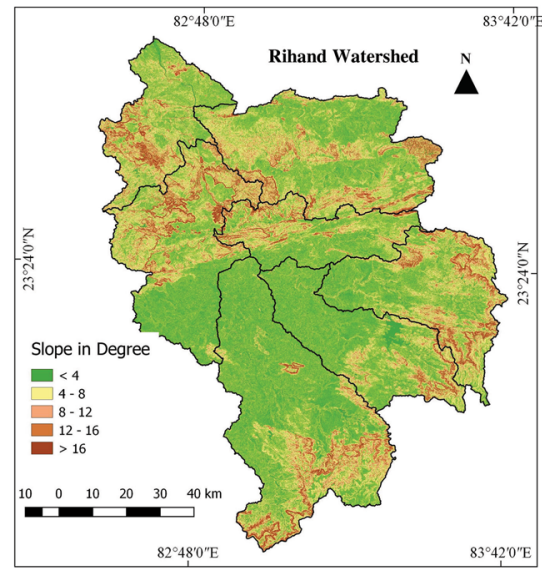

[5]

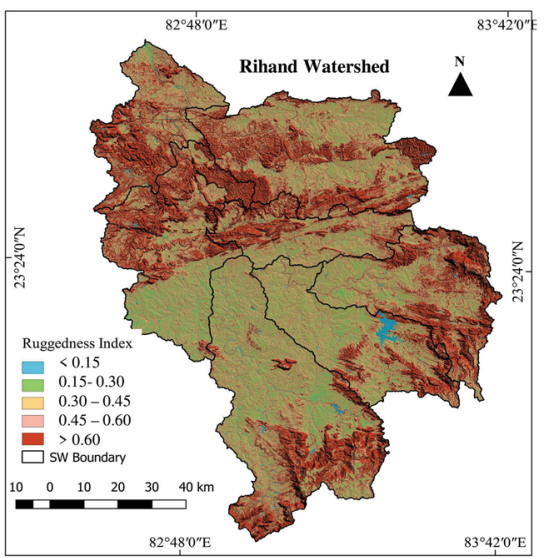

[3]

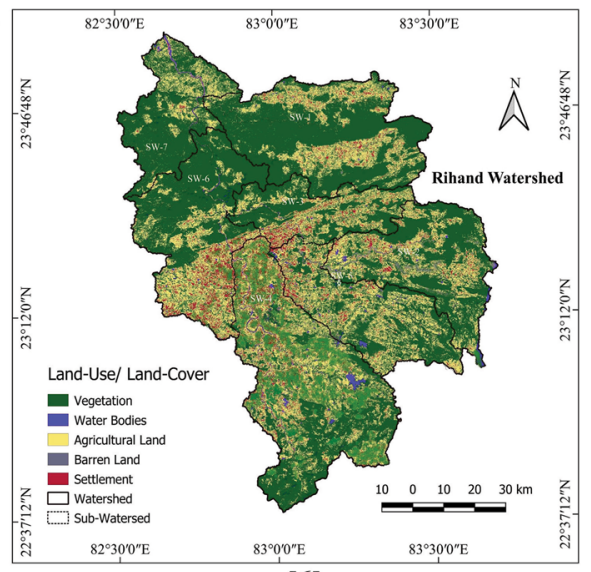

[6]

Fig. 5 a Stream ordering; b Drainage density; c Ruggedness ratio; d Relief; e Slope; f Land-use/land-cover map

Texture is classified into four categories $<4$ per $\mathrm{km}$ coarse, 4-10 per km intermediate, $10-15$ per $\mathrm{km}$ fine and $>15$ per $\mathrm{km}$ ultra fine (Choudhari et al. 2018). Texture ratio for all 7 sub-watersheds varies from 0.55 to 1.12 (Table 4) which indicates that the entire watershed falls under coarse category.

\section{Circulatory ratio $\left(R_{\mathrm{c}}\right)$}

Circulatory ratio is the most useful shape measure in correlation with stream flow (Morisawa 1959) can be define as the ratio of the basin area to the area of a circle proportionate with the same perimeter as the basin (Miller 1953). The values of circulatory ratio range between 0 and 1 , while 1 indicated a perfect round shape and low the value express high degree of irregularity and early stage of life cycle. The circulatory ratio for Rihand sub-watershed falls between 0.15 and 0.21 (Table 4) which indicates high relief with less circular basin characterized by youth stage of development.
Lowest $R_{\mathrm{c}}$ in SW-2 exposing higher rate in erosion and least infiltration and seeking greater attention for conservation.

\section{Elongation ratio $\left(R_{\mathrm{e}}\right)$}

Elongation ratio is the ratio between the diameter of a circle with the same area of a basin and the maximum length of that basin (Schumm 1956). The value 1 indicates a complete circular shape with very low relief of the drainage basin and produces a high peak discharge while low value of $R_{\mathrm{e}}$ elongated shape with high relief and steep slope. Thus, $R_{\mathrm{e}}$ is very useful for flood forecasting. Elongation ratio of a river basin depends on structure, lithology, climate, relief, slope and pattern of LU/LC. The values of the elongation ratio generally vary from 0.6 to 1.0 over a large variety of climatic and geologic types (Choudhari et al. 2018; Rudraiah et al. 2008). Elongation ratio varies from 0.54 to 0.72 (Table 4) which expressed that lower to average peak flow of longer duration, with high relief, steep slope and elongated basin. 


\section{Form factor $\left(R_{\mathrm{f}}\right)$}

Form factor is simply ratio between area and square of the length of a watershed. Horton (1932) stated that the length to be used is not necessarily the maximum length but is to be measured from a point on the watershed-line opposite the head of the main stream. In this study Form factor has been calculated by measuring length of each basin from the mouth to the opposite side (Morisawa 1959). In this study the form factor of all the 7 sub-watersheds ranges from 0.24 to 0.41 (Table 4). SW-3 and SW-5 has recorded lowest value of $R_{\mathrm{f}}$ which indicates flatter peak flow for longer duration of discharge and SW-2 has recorded highest $R_{\mathrm{f}}(0.41)$ followed by SW-6 and SW-7 characterized by relatively high peak discharge.

\section{Compactness constant $\left(C_{c}\right)$}

Gravelius introduced Compactness Index as the ratio of the perimeter of the drainage basin to the perimeter of a circle with equal area (Horton 1932). Lowe value of Compactness index indicates an ideal circular shape. Two watersheds with same areal extension but different Compactness index approaches difference in hydrologic characteristics. In this study $C_{c}$ of 7 sub-watersheds is shown in Table 4 which indicates diversity among the sub-watershed in surface hydrology.

\section{Form factor $\left(R_{\mathrm{f}}\right)$}

Form factor is simply ratio between area and square of the length of a watershed. Horton (1932) stated that the length to be used is not necessarily the maximum length but is to be measured from a point on the watershed-line opposite the head of the main stream. In this study form factor has been calculated by measuring length of each basin from the mouth to the opposite side (Morisawa 1959). In this study the form factor of all the 7 sub-watersheds ranges from 0.24 to 0.41 (Table 4). SW-3 and SW-5 has recorded lowest value of $R_{\mathrm{f}}$ which indicates flatter peak flow for longer duration of discharge and SW-2 has recorded highest $R_{\mathrm{f}}(0.41)$ followed by SW- 6 and SW-7 characterized by relatively high peak discharge.

\section{Relative relief $\left(R_{\mathrm{r}}\right)$}

Total relief has a direct impact on hydrological behavior of the watershed and may be defined as the difference between maximum elevation and minimum elevation within the boundary of watershed (Hadley and Schumm 1961). Total relief for each of 7 sub-watersheds has been computed by capturing value of maximum and minimum elevation from DEM. The value of $R_{h}$ ranges from 583 to 774.90 (Table 4).
Relief ratio $\left(R_{h}\right)$

Schumm (1956) defined as the ratio between the total relief of a basin (elevation difference of lowest and highest points of a basin) and the longest dimension of the basin parallel to the principal drainage line. The maximum $R_{h}$ values of is 0.0133 (Table 4), has recorded in SW-7 which signifying the presence of higher relief underlain by resistant rocks and lowest value of $R_{\mathrm{r}} 0.0078$ (Table 4 ) has recorded in SW-4 which indicates relatively low relief and more denudation.

\section{Ruggedness number $\left(R_{\mathrm{n}}\right)$}

Ruggedness Number has devised by R J Chorley can be expressed by multiplication amplitude of relief with drainage density (Sen 1993). It indicates the undulation of relief and implies to compute the flood potentiality of watersheds (Hembram and Saha 2020). The value of ruggedness number is proportionately associated with risk of erosion and inversely related with rate of infiltration. Therefore, SW-2 is more exposed to erosion with an index value of 0.60 (Table 4) comparing to rest. SWS-1, 4 and 5 has the least ' $R_{\mathrm{n}}$ ' value $(<0.45)$ with less erosion threat and rest of the sub-watersheds falls under moderate class (Fig. $5 \mathrm{c}$ )

\section{Stream gradient $\left(S_{g}\right)$}

The stream gradient $\left(S_{\mathrm{g}}\right)$ is simply different in elevation between source and mouth point of a river which is related to the power of a stream to transport material of a given size and to the characteristics of the bedrocks that resist flow (Hack 1957). Thus, it is a geometric property that can quantitatively describe rate of erosion, runoff and nature peak discharge. The high value of stream gradient of has recorded in SW-2, SW-4 and SW-7 (> 250) (Table 4) which indicates high relief and steep slope, and high runoff, while SW-1 and SW-3 has the low value $(<150)$ which indicates gentle slope and more efficient in discharge of runoff. A compound long profile for the entire watershed has been prepared (Fig. 6) for the better understanding of the stream gradient.

\section{Hypsometric integral (HI)}

The hypsometric integral (HI) is related to the uplift rate and recently uplifts anticlines in the tectonically active region (Sangma and Guru 2020; Hurtrez et al. 1999). The hypsometric integral (HI) value for entire Rihand watershed lies between 0.22 and 0.34, (Table 4). SW-2 and SW-7 has recorded highest value $(>0.45)$ indicates high risk of erosion on the other hand lowest value of Hypsometric integral in SW- 1 and SW-5 $(<0.22)$ expresses old and low risk of erosion. Sub-watershed wise relative hypsometric curve has been plotted (Fig. 7) which showing diversity in erodibility. 


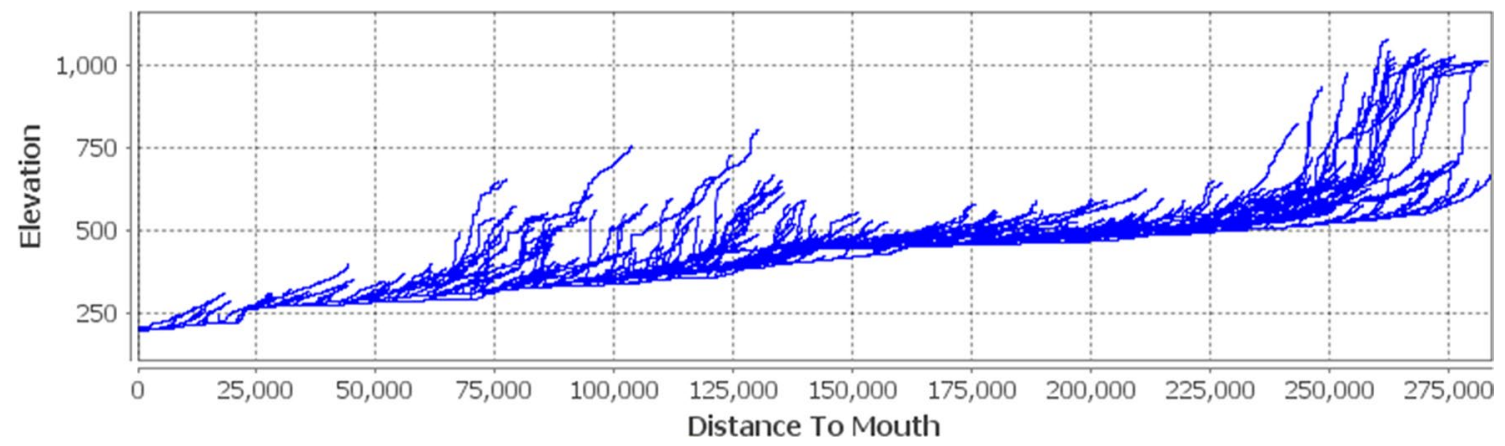

Fig. 6 Long profile (elevation and distance in meter)

\section{Land use/land cover}

Increasing population at a rapid rate has often leads alteration of land-use/land-cover pattern of an area through deforestation, settlement, agriculture, infrastructural development, etc. If the present need is fulfilled in unplanned manner, it will deteriorate the watershed. The rate of soil erosion is directly proportional to the runoff and the rate of flow is directly proportional to the settlement, fallow land, wasteland and water and inversely proportional to shrubland, agricultural land, and forestland. Thus, in order to conserve water and soil resources in a sustainable way, a systematic management of land use is required. In present study Land-use/Land-cover map (Fig. 5e) of the entire watershed has been prepared using LANDSAT ETM + image. It was found that $43.80 \%$ of the entire watershed area is covered with forest while agricultural land and settlement occupied $29.19 \%$ and $14.60 \%$ of the total area, respectively. Water body covered $8.94 \%$ of the total land and rest of the area of the watershed is under Barren land (Table 5).

\section{Prioritization of sub-watersheds}

All sub-watersheds are considered as a hydrological unit as they are unique in terms of morphometric characteristics and hydrological response. Thus, it is important to identify crucial sub-watersheds under a watershed for planning and management. In this view selection of appropriate parameters and assigned them most suitable weightage is the most challenging part of watershed
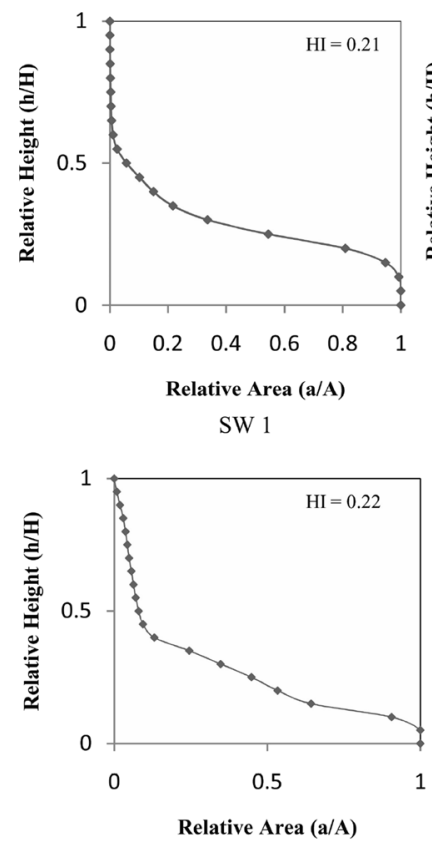

SW 5
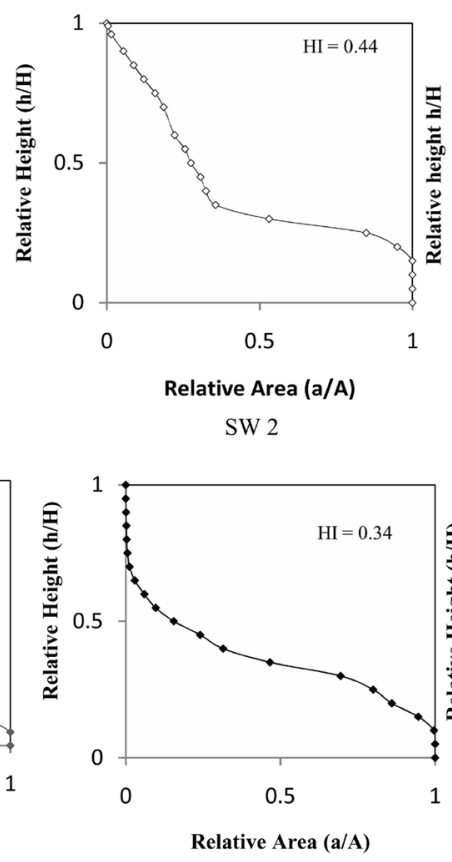

SW 6
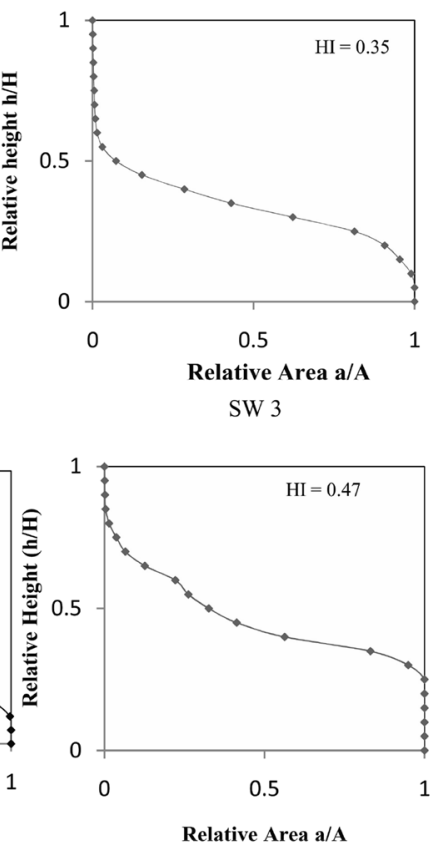

SW 7

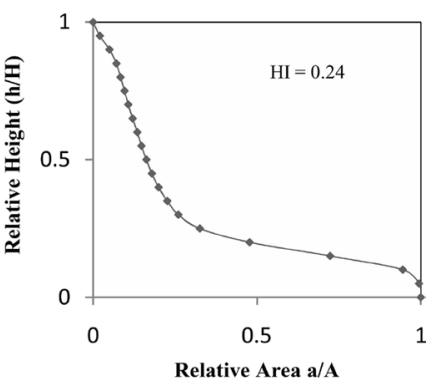

SW 4

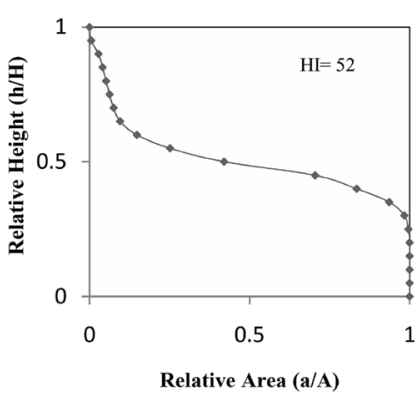

Entire Watershed

Fig. 7 Hypsometric curve (relative) 
Table 5 Pair-wise comparison matrix for fuzzy AHP

\begin{tabular}{|c|c|c|c|c|c|c|c|c|}
\hline Parameters & $L_{\mathrm{sm}}$ & $D_{\mathrm{d}}$ & $D_{\mathrm{f}}$ & $R_{\mathrm{t}}$ & $R_{\mathrm{bm}}$ & $C_{\mathrm{c}}$ & $R_{\mathrm{f}}$ & $R_{\mathrm{e}}$ \\
\hline$L_{\mathrm{sm}}$ & $(1,1,1)$ & $(1 / 3,1 / 2,1)$ & $(1 / 3,1 / 2,1)$ & $(1 / 4,1 / 3,1 / 2)$ & $(1 / 5,1 / 4,1 / 3)$ & $(1 / 5,1 / 4,1 / 3)$ & $(1 / 6,1 / 5,1 / 4)$ & $(1 / 6,1 / 5,1 / 4)$ \\
\hline$D_{\mathrm{d}}$ & $(1,2,3)$ & $(1,1,1)$ & $(1 / 3,1 / 2,1)$ & $(1 / 3,1 / 2,1)$ & $(1 / 4,1 / 3,1 / 2)$ & $(1 / 5,1 / 4,1 / 3)$ & $(1 / 5,1 / 4,1 / 3)$ & $(1 / 5,1 / 4,1 / 3)$ \\
\hline$D_{\mathrm{f}}$ & $(1,2,3)$ & $(1,2,3)$ & $(1,1,1)$ & $(1 / 3,1 / 2,1)$ & $(1 / 3,1 / 2,1)$ & $(1 / 5,1 / 4,1 / 3)$ & $(1 / 5,1 / 4,1 / 3)$ & $(1 / 5,1 / 4,1 / 3)$ \\
\hline$R_{\mathrm{t}}$ & $(2,3,4)$ & $(1,2,3)$ & $(1,2,3)$ & $(1,1,1)$ & $(1 / 3,1 / 2,1)$ & $(1 / 4,1 / 3,1 / 2)$ & $(1 / 5,1 / 4,1 / 3)$ & $(1 / 5,1 / 4,1 / 3)$ \\
\hline$R_{\mathrm{bm}}$ & $(3,4,5)$ & $(2,3,4)$ & $(1,2,3)$ & $(1,2,3)$ & $(1,1,1)$ & $(1 / 4,1 / 3,1 / 2)$ & $(1 / 4,1 / 3,1 / 2)$ & $(1 / 5,1 / 4,1 / 3)$ \\
\hline$C_{\mathrm{c}}$ & $(3,4,5)$ & $(3,4,5)$ & $(3,4,5)$ & $(2,3,4)$ & $(2,3,4)$ & $(1,1,1)$ & $(1 / 3,1 / 2,1)$ & $(1 / 3,1 / 2,1)$ \\
\hline$R_{\mathrm{f}}$ & $(4,5,6)$ & $(3,4,5)$ & $(3,4,5)$ & $(3,4,5)$ & $(2,3,4)$ & $(1,2,3)$, & $(1,1,1)$ & $(1 / 3,1 / 2,1)$ \\
\hline$R_{\mathrm{e}}$ & $(4,5,6)$ & $(3,4,5)$ & $(3,4,5)$ & $(3,4,5)$ & $(3,4,5)$ & $(1,2,3)$ & $(1,2,3)$ & $(1,1,1)$ \\
\hline$R_{\mathrm{c}}$ & $(5,6,7)$ & $(4,5,6)$ & $(4,5,6)$ & $(3,4,5)$ & $(3,4,5)$ & $(2,3,4)$ & $(2,3,4)$ & $(1,2,3)$ \\
\hline$O_{1}$ & $(5,6,7)$ & $(5,6,7)$ & $(4,5,6)$ & $(4,5,6)$ & $(3,4,5)$ & $(2,3,4)$ & $(2,3,4)$ & $(2,3,4)$ \\
\hline$I_{\mathrm{f}}$ & $(6,7,8)$ & $(5,6,7)$ & $(5,6,7)$ & $(5,6,7)$ & $(4,5,6)$ & $(3,4,5)$ & $(3,4,5)$ & $(3,4,5)$ \\
\hline$S_{\mathrm{g}}$ & $(6,7,8)$ & $(6,7,8)$ & $(5,6,7)$ & $(5,6,7)$ & $(4,5,6)$ & $(3,4,5)$ & $(3,4,5)$ & $(3,4,5)$ \\
\hline HI & $(6,7,8)$ & $(6,7,8)$ & $(5,6,7)$ & $(5,6,7)$ & $(5,6,7)$ & $(4,5,6)$ & $(4,5,6)$ & $(3,4,5)$ \\
\hline$R_{\mathrm{n}}$ & $(7,8,9)$ & $(6,7,8)$ & $(6,7,8)$ & $(6,7,8)$ & $(5,6,7)$ & $(4,5,6)$ & $(4,5,6)$ & $(4,5,6)$ \\
\hline$\underline{R_{h}}$ & $(7,8,9)$ & $(6,7,8)$ & $(6,7,8)$ & $(5,6,7)$ & $(5,6,7)$ & $(5,6,7)$ & $(5,6,7))$ & $(4,5,6)$ \\
\hline Parameters & $R_{\mathrm{c}}$ & $O_{1}$ & $I_{\mathrm{f}}$ & $S_{\mathrm{g}}$ & $\mathrm{HI}$ & $R_{\mathrm{n}}$ & $R_{h}$ & $X_{i}$ \\
\hline$L_{\mathrm{sm}}$ & $(1 / 7,1 / 6,1 / 5)$ & $(1 / 7,1 / 6,1 / 5)$ & $(1 / 8,1 / 7,1 / 6)$ & $(1 / 8,1 / 7,1 / 6)$ & $(1 / 8,1 / 7,1 / 6)$ & $(1 / 9,1 / 8,1 / 7)$ & $(1 / 9,1 / 8,1 / 7)$ & 0.011 \\
\hline$D_{\mathrm{d}}$ & $(1 / 6,1 / 5,1 / 4)$ & $(1 / 7,1 / 6,1 / 5)$ & $(1 / 7,1 / 6,1 / 5)$ & $(1 / 8,1 / 7,1 / 6)$ & $(1 / 8,1 / 7,1 / 6)$ & $(1 / 8,1 / 7,1 / 6)$ & $(1 / 8,1 / 7,1 / 6)$ & 0.013 \\
\hline$D_{\mathrm{f}}$ & $(1 / 6,1 / 5,1 / 4)$, & $(1 / 6,1 / 5,1 / 4)$ & $(1 / 7,1 / 6,1 / 5)$ & $(1 / 7,1 / 6,1 / 5)$ & $(1 / 8,1 / 7,1 / 6)$ & $(1 / 8,1 / 7,1 / 6)$ & $(1 / 8,1 / 7,1 / 6)$ & 0.015 \\
\hline$R_{\mathrm{t}}$ & $(1 / 5,1 / 4,1 / 3)$ & $(1 / 6,1 / 5,1 / 4)$ & $(1 / 7,1 / 6,1 / 5)$ & $(1 / 7,1 / 6,1 / 5)$ & $(1 / 7,1 / 6,1 / 5)$ & $(1 / 8,1 / 7,1 / 6)$ & $(1 / 7,1 / 6,1 / 5)$ & 0.017 \\
\hline$R_{\mathrm{bm}}$ & $(1 / 5,1 / 4,1 / 3)$ & $(1 / 5,1 / 4,1 / 3)$ & $(1 / 6,1 / 5,1 / 4)$ & $(1 / 6,1 / 5,1 / 4)$ & $(1 / 7,1 / 6,1 / 5)$ & $(1 / 7,1 / 6,1 / 5)$ & $(1 / 7,1 / 6,1 / 5)$ & 0.021 \\
\hline$C_{\mathrm{c}}$ & $(1 / 4,1 / 3,1 / 2)$ & $(1 / 4,1 / 3,1 / 2)$ & $(1 / 5,1 / 4,1 / 3)$ & $(1 / 5,1 / 4,1 / 3)$ & $(1 / 6,1 / 5,1 / 4)$ & $(1 / 6,1 / 5,1 / 4)$ & $(1 / 7,1 / 6,1 / 5)$ & 0.169 \\
\hline$R_{\mathrm{f}}$ & $(1 / 4,1 / 3,1 / 2)$ & $(1 / 4,1 / 3,1 / 2)$ & $(1 / 5,1 / 4,1 / 3)$ & $(1 / 5,1 / 4,1 / 3)$ & $(1 / 6,1 / 5,1 / 4)$ & $(1 / 6,1 / 5,1 / 4)$ & $(1 / 7,1 / 6,1 / 5)$ & 0.033 \\
\hline$R_{\mathrm{e}}$ & $(1,2,3)$ & $(1 / 3,1 / 2,1)$ & $(1 / 5,1 / 4,1 / 3)$ & $(1 / 5,1 / 4,1 / 3)$ & $(1 / 5,1 / 4,1 / 3)$ & $(1 / 6,1 / 5,1 / 4)$ & $(1 / 6,1 / 5,1 / 4)$ & 0.038 \\
\hline$R_{\mathrm{c}}$ & $(1,1,1)$ & $(1 / 3,1 / 2,1)$ & $(1 / 3,1 / 2,1)$ & $(1 / 4,1 / 3,1 / 2)$ & $(1 / 5,1 / 4,1 / 3)$ & $(1 / 5,1 / 4,1 / 3)$ & $(1 / 6,1 / 5,1 / 4)$ & 0.045 \\
\hline$O_{1}$ & $(1,2,3)$ & $(1,1,1)$ & $(1 / 3,1 / 2,1)$ & $(1 / 3,1 / 2,1)$ & $(1 / 4,1 / 3,1 / 2)$ & $(1 / 5,1 / 4,1 / 3)$ & $(1 / 5,1 / 4,1 / 3)$ & 0.06 \\
\hline$I_{\mathrm{f}}$ & $(1,2,3)$ & $(1,2,3)$ & $(1,1,1)$ & $(1 / 3,1 / 2,1)$ & $(1 / 3,1 / 2,1)$ & $(1 / 5,1 / 4,1 / 3)$ & $(1 / 4,1 / 3,1 / 2)$ & 0.075 \\
\hline$S_{\mathrm{g}}$ & $(2,3,4)$ & $(1,2,3)$ & $(1,2,3)$ & $(1,1,1)$ & $(1 / 3,1 / 2,1)$ & $(1 / 4,1 / 3,1 / 2)$ & $(1 / 4,1 / 3,1 / 2)$ & 0.093 \\
\hline $\mathrm{HI}$ & $(3,4,5)$ & $(2,3,4)$ & $(1,2,3)$ & $(1,2,3)$ & $(1,1,1$ & $(1 / 3,1 / 2,1)$ & $(1 / 3,1 / 2,1)$ & 0.11 \\
\hline$R_{\mathrm{n}}$ & $(3,4,5)$ & $(3,4,5)$ & $(2,3,4)$ & $(2,3,4)$ & $(1,2,3)$ & $(1,1,1$ & $(1 / 3,1 / 2,1)$ & 0.135 \\
\hline$R_{h}$ & $(4,5,6)$ & $(3,4,5)$ & $(2,3,4))$ & $(2,3,4)$ & $(1,2,3)$, & $(1,2,3)$, & $(1,1,1)$ & 0.163 \\
\hline
\end{tabular}

prioritization. Considering previous contributions (Sangma and Guru, 2020; Mishra et al. 2018; Ahmed et al. 2017; Rahaman, et al. 2015; Aher et al. 2014; Thomas et al. 2012; Magesh et al. 2011; Suresh et al. 2004; Khan et al. 2001) linear aspect such as bifurcation ratio $\left(R_{\mathrm{b}}\right)$, Mean Stream length and Length of overland $\left(O_{1}\right)$; Areal aspect such as drainage density $\left(D_{\mathrm{d}}\right)$, stream frequency $\left(F_{\mathrm{s}}\right)$, drainage texture $\left(D_{\mathrm{t}}\right)$, Shape factor $\left(F_{\mathrm{s}}\right)$, circularity ratio $\left(R_{\mathrm{c}}\right)$, and elongation ratio; and relief factors such as relief ratio $\left(R_{\mathrm{r}}\right)$, ruggedness number $\left(R_{\mathrm{n}}\right)$ Stream Gradient (SL) and Hypsometric Integral (HI) have been selected to prioritize sub-watersheds as these are directly termed with surface runoff, soil erosion and other hazardous phenomena. Uncertainty in morphometric parameters was overcome by assigning triangular fuzzy numbers (TFN) to morphometric parameters on the basis of their influence on resource degradation (Ahmed et al. 2017). To assign weights to the selected parameters, triangular fuzzy number has been used at 9 point scale, i.e., equally important $(1,1,1),(1,2,3),(2,3,4),(3,4,5)$, $(4,5,6)(5,6,7),(6,7,8),(7,8,9)$, extremely important for pair-wise comparison. Morphometric parameters those are inversely correlated with erosion hazard such as Shape factor $\left(F_{\mathrm{s}}\right)$, circularity ratio $\left(R_{\mathrm{c}}\right)$, and elongation ratio membership value assigned inversely correspondent to index value, i.e., lower the value of shape parameters was higher the membership value was assigned. Rests of the parameters are directly correlated with erodibility thus highest TFN were assigned to the most important criteria as shown in Table 6.

After compute criterion weights for each parameter through FAHP alternative weight has been assigned to 
each sub-watershed through normalizing the values of morphometric parameters (Table 6). In case of those parameters which are directly correlated with erodibility, normalized value has obtained by dividing the actual value by highest value among the 7 sub-watershed for the same parameter on the other hand parameters which are inversely correlated with erodibility normalized value has obtained by dividing the lowest value of a parameter among 7 sub-watershed by actual value of each sub-watershed.

The final values of priority assessment $\left(F_{j}\right)$ have been obtained for different sub-watersheds by multiply criterion weight with normalized morphometric parameters weights (Table 7). The prioritization values obtained from morphometric parameters through using fuzzy AHP ranges between 0.100 and 0.200 (Fig. 9b) which categorized into 3 category, i.e., highly prioritized ( $>0.15$ ), Moderately prioritized $(0.125-0.15)$ and Low prioritization category (Fig. 9a).

\section{Discussion}

The analyzed results of sub-watersheds' prioritization using FAHP (Table 7 and Fig. 9) depicted that out of 7 sub-watersheds, 2 sub-watersheds (SW-2 and SW-6) covering a total area of $3450.20 \mathrm{~km}^{2}$ could be categorized as high priority in which soil conservation measures and catchment area treatment plan would be urgently necessary. These watersheds have high altitude, moderate slopes with high drainage density $\left(\mathrm{D}_{\mathrm{d}}\right)$ and length of the overland flow $\left(L_{\mathrm{o}}\right)$ which supports to more surface erosion. Least value of Circularity ratio $\left(R_{\mathrm{c}}\right)$ and higher value of form factor $\left(R_{\mathrm{f}}\right)$ in these sub-watersheds indicates relatively high peak discharge which increase the erodibility of soil. Other 3 sub-watersheds (SW-3, SW-4 and SW-7) occupied an area of $4192.53 \mathrm{~km}^{2}$. Could be put under moderately prioritized categories which are located near reservoir also need measures for soil conservations. Moderate erosion can be observed in these watersheds as higher value of Texture Ratio $\left(R_{\mathrm{t}}\right)$, Drainage frequency $\left(F_{\mathrm{d}}\right)$ and Bifurcation ratio $\left(R_{\mathrm{bm}}\right)$. Rest of the Sub-watershed (SW-1 and SW-5) are categorized as a low prioritization which can be bringing under the part of conservation plan at later stage. These watersheds are characterized by low drainage density, plain surface and low erosion activities with comparatively good agriculture. Well irrigation in rainy season is observed for commercial crops near to streams. Therefore, these watersheds are suggested with comparatively low priorities for planning and development. Present study revealed the utility of hydro-morphometric-based prioritization study before adopting any comprehensive plan for watershed at micro-level. In the purpose of investigation at micro scale
Table 6 Normalized value of morphometric parameters $\left(W_{i j}\right)$

\begin{tabular}{llllllll}
\hline Parameters & SW1 & SW2 & SW3 & SW4 & SW5 & SW6 & SW7 \\
\hline$L_{\mathrm{sm}}$ & 0.155 & 0.158 & 0.1137 & 0.24 & 0.095 & 0.135 & 0.101 \\
$D_{\mathrm{d}}$ & 0.132 & 0.134 & 0.201 & 0.13 & 0.136 & 0.128 & 0.138 \\
$D_{\mathrm{f}}$ & 0.152 & 0.094 & 0.156 & 0.133 & 0.159 & 0.143 & 0.162 \\
$R_{\mathrm{t}}$ & 0.172 & 0.085 & 0.119 & 0.167 & 0.16 & 0.154 & 0.141 \\
$R_{\mathrm{bm}}$ & 0.14 & 0.151 & 0.13 & 0.206 & 0.127 & 0.133 & 0.11 \\
$C_{\mathrm{c}}$ & 0.144 & 0.156 & 0.145 & 0.147 & 0.131 & 0.141 & 0.133 \\
$R_{\mathrm{f}}$ & 0.135 & 0.109 & 0.186 & 0.135 & 0.186 & 0.121 & 0.124 \\
$R_{\mathrm{e}}$ & 0.141 & 0.125 & 0.164 & 0.138 & 0.167 & 0.13 & 0.132 \\
$R_{\mathrm{c}}$ & 0.147 & 0.177 & 0.156 & 0.165 & 0.126 & 0.094 & 0.132 \\
$O_{1}$ & 0.15 & 0.15 & 0.098 & 0.156 & 0.146 & 0.154 & 0.144 \\
$I_{\mathrm{f}}$ & 0.082 & 0.293 & 0.17 & 0.085 & 0.113 & 0.107 & 0.146 \\
$S_{\mathrm{g}}$ & 0.059 & 0.27 & 0.067 & 0.176 & 0.098 & 0.187 & 0.14 \\
$\mathrm{HI}$ & 0.093 & 0.212 & 0.133 & 0.105 & 0.096 & 0.152 & 0.206 \\
$R_{\mathrm{n}}$ & 0.105 & 0.188 & 0.153 & 0.139 & 0.128 & 0.163 & 0.121 \\
$R_{h}$ & 0.097 & 0.224 & 0.116 & 0.121 & 0.116 & 0.168 & 0.158 \\
\hline
\end{tabular}

Table 7 Prioritization values and rank

\begin{tabular}{llllllll}
\hline Sub-watersheds & SW1 & SW2 & SW3 & SW4 & SW5 & SW6 & SW7 \\
\hline $\begin{array}{l}\text { Prioritization score } \\
\quad 0.100\end{array}$ & 0.200 & 0.133 & 0.135 & 0.123 & 0.151 & 0.136 \\
$\quad \begin{array}{l}F_{j}=\sum\left(X_{i} * W_{i j}\right) \\
\text { Priority rank }\end{array}$ & 7 & 1 & 5 & 4 & 6 & 2 & 3 \\
Vulnerable zone & Low & High & Medium & Medium & Low & High & Medium \\
\hline
\end{tabular}


it is impotent to study sub-watershed because each of these have some strengths and some challenges and to address those challenges and utilize their strength it is essential to study morphometric configuration of the sub-watershed at micro scale.

Though land-use/land-cover data have not used in prioritization of the sub-watersheds but the results obtained from Land-use/Land-cover analysis can be directly correlate with land and water resource deterioration. LU/LC information derived from the satellite imaginaries and their integration with GIS can be useful for estimation of runoff, infiltration, evaporation, soil erosion and sediment yield (Prabhakar et al. 2019). It was found that Sub-watershed 6 and sub-watershed-2 occupied highest percentage of settlement area, barren land and agricultural land which leads more soil erosion and minimize infiltration. On the other hand, subwatershed 1 and 5 have highest percentage of forest cover area which leads infiltration, thus low priority has been assign to these sub-watersheds. Therefore, morphometric

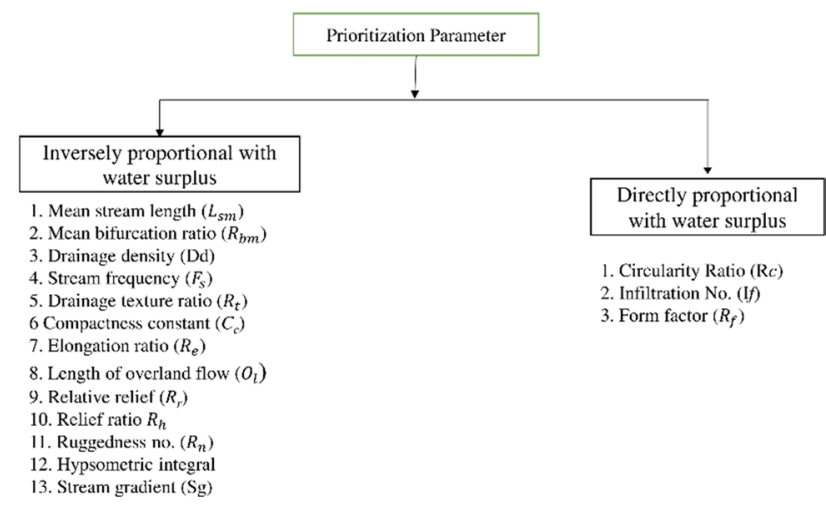

Fig. 8 Morphometric parameter used for sub-watershed prioritization and their relation with water surplus and Land-Use/Land-Cover analysis are quite useful soil and water resource conservation, management and planning of a watersheds.

\section{Suitability measures}

Morphometric analysis based on Remote sensing GIS techniques would serve as a powerful tool in watershed prioritization and management considering multiple criterions and their complex interrelationship. The purpose of applying multicriteria decision-making techniques is to exercise a proper approach to identify areas of high- priority for watershed management. Water and soil resources management decisions depend on timing of runoff characteristics and runoff characteristics of a watershed depends on surface hydrology, surface relief, slope lithology, basin geometry and other morphometric parameters. Figure 8 showing relationship between morphometric parameters and water surplus where Circularity Ratio $\left(R_{\mathrm{c}}\right)$, Infiltration No. $\left(I_{\mathrm{f}}\right)$ and Form factor $\left(R_{\mathrm{f}}\right)$ are directly proportionate with water surplus, as they increase rate of infiltration. Rest of the 13 parameters used in sub-watershed prioritization are inversely correlated with water surpluses as they promote surface runoff. Therefore, morphometric parameters are useful tool for sustainable management plan for soil and water resources. Based on result of morphometric-based prioritization analysis and by overlaying drainage ruggedness, Relief (Fig. 5d) slope map (Fig. 5e) and land-use/Land-cover map a suitable location for conservation measure structure consist of 12 Check dam, 40 Percolation tank and 65 Nala bund has been proposed to minimize soil erosion and promote groundwater recharge. As prioritization study has revealed that SW-2 and SW-6 are the most critical sub-watersheds in terms of erodibility thus a large number (total 46) of conservation measure structures sites was suggested out of these out of which 22

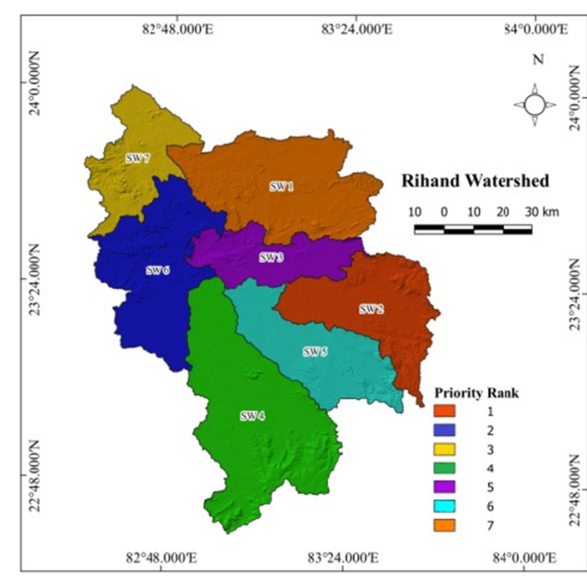

(a)

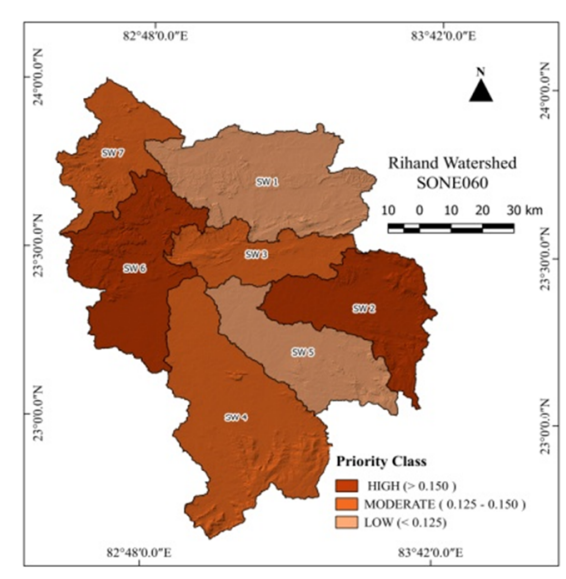

(b)

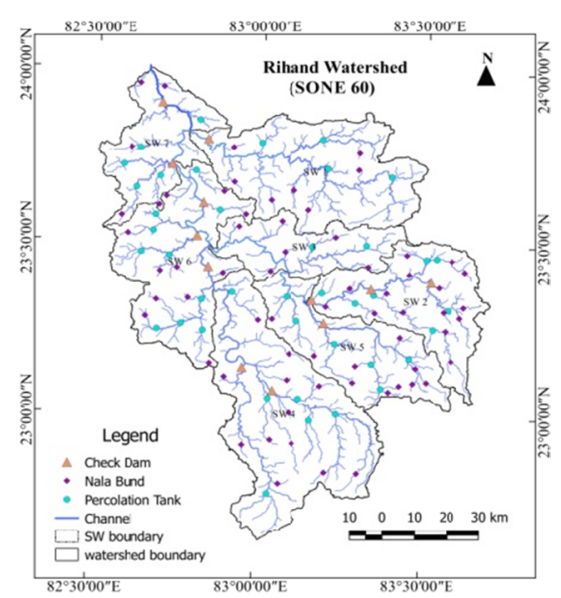

(c)

Fig. 9 a, b Prioritization map of the watersheds; c Location for conservation measure structure 
sites for nala bund, 18 sites for percolation tank and 6 sites for the check dam (Fig. 9c). This study will not only help to planner and decision maker to take watershed development plan for land and water resource management in an effective way but also promote sustainable development through increase in agricultural production.

\section{Conclusion}

Morphometric analysis of watersheds is useful to reveal relationship among different aspects of the drainage basin including geology surface hydrology and climatic condition which are closely associated with erodibility, groundwater recharge, flood susceptibility and other hazardous phenomena. Therefore, priority analysis of sub-watersheds based on morphometric parameters is essential in soil and water resource conservation, construction of an integrated framework for watershed development, and to increase awareness of natural hazards. In present study a GIS-based prioritization of sub-watersheds has carried out based on morphometric parameters using Multicriteria Decision making (MCDM) to evaluate usefulness of morphometric parameters in the identification of soil erosion and groundwater potential zonation. Morphological characterization has been carried out through the measurement of linear, areal, and relief aspects to figure out hydrological behavior of the watershed with concern about soil and water resource depletion. In present study it has found that SW2 and SW6 are falls in the high priority category which indicating greater risk of erosion and most deficit zone of groundwater and may be taken for immediate conservation measurement by planning authority. SW 3, SW 4 and SW 7 are characterized by moderate soil erosion and groundwater recharge. SW 1 and SW 5 are ideal for groundwater storage as falls in the low priority zone. On the basis of priority analysis, a framework for the construction of small storage dam (check dams) in the area to recharge the groundwater and further to improve the water table and minimize soil erosion has been proposed which may be taken for conservation measurement by decision maker for planning and development.

\section{Scope and limitation}

This study revealed the applicability of morphometric analysis in prioritization of sub-watersheds to conserve soil and water resources. The result obtained from this study would be quite useful for hydrologic engineers for planning and management. Land-use/land-cover data in sub-watersheds is also helpful for management of soil and water resource. This study also revealed the benefits of remote sensing data and GIS techniques in morphometric analysis and land-use/ land-cover analysis based on which further study may be carried out for sustainable management of soil and water resource.

Major limitation of this study area-unavailability of secondary data regarding water discharge, soil, land-use, etc. SRTM-DEM used in this study have 90-m spatial resolution so vertical accuracy is not enough for a plain land area. Thus, lack of high-resolution DEM is another limitation of this study.

Acknowledgements I the undersigned solemnly declare that this work is totally an original contribution has been done by the authors. The entire work or its part has not been submitted to any other Institution for any other degree/diploma/certificate in this university or any other University of India or abroad. Whenever materials (data, theoretical analysis, and text) from other sources have been used, credit has been given to them in the text of the report and their details in the references. Milan Ghosh University of Kalyani.

Funding The author(s) received no specific funding for this work.

\section{Compliance with ethical standards}

Conflict of interest The authors declare that they have no conflict of interest.

Open Access This article is licensed under a Creative Commons Attribution 4.0 International License, which permits use, sharing, adaptation, distribution and reproduction in any medium or format, as long as you give appropriate credit to the original author(s) and the source, provide a link to the Creative Commons licence, and indicate if changes were made. The images or other third party material in this article are included in the article's Creative Commons licence, unless indicated otherwise in a credit line to the material. If material is not included in the article's Creative Commons licence and your intended use is not permitted by statutory regulation or exceeds the permitted use, you will need to obtain permission directly from the copyright holder. To view a copy of this licence, visit http://creativecommons.org/licenses/by/4.0/.

\section{References}

Adhami M, Sadeghi SH, Duttmann R, Sheikhmohammady M (2019) Changes in watershed hydrological behavior due to land use comanagement scenarios. J Hydrol 577:124001

Agarwal C (1998) Study of drainage pattern through aerial data in Naugarh area of Varanasi district, U.P. J Indian Soc Remote Sens 26(4):169-175. https://doi.org/10.1007/bf02990795

Aher P, Adinarayana J, Gorantiwar SD (2013) Prioritization of watersheds using multi-criteria evaluation through fuzzy analytical hierarchy process. Agric Eng Int CIGR J 15(1):11-18

Aher P, Adinarayana J, Gorantiwar S (2014) Quantification of morphometric characterization and prioritization for management planning in semi-arid tropics of India: a remote sensing and GIS approach. J Hydrol 511:850-860. https://doi.org/10.1016/j.jhydr ol.2014.02.028

Ahmadisharaf E, Kalyanapu AJ, Chung ES (2015) Evaluating the effects of inundation duration and velocity on selection of flood management alternatives using multi-criteria decision making. Water Resour Manag 29(8):2543-2561 
Ahmed R, Sajjad H, Husain I (2017) Morphometric parameters-based prioritization of sub-watersheds using fuzzy analytical hierarchy process: a case study of lower Barpani watershed, India. Nat Resour Res 27(1):67-75. https://doi.org/10.1007/s1105 3-017-9337-4

Balasubramani K, Gomathi M, Bhaskaran G, Kumaraswamy K (2019) GIS-based spatial multi-criteria approach for characterization and prioritization of micro-watersheds: a case study of semi-arid watershed, South India. Appl Geomat 11(3):289-307

Bats RL, Jackson J (1987) Glossary of geology. American Geological Institute, Alexandria, p 788

Bhattacharyya A (1996) Recent advances in Vindhyan geology. Geol Soc India Memoir 36:331

Biswas S, Sudhakar S, Desai VR (1999) Prioritisation of subwatershed based on morphometric analysis of drainage basin: a remote sensing and GIS approach. J Indian Soc Remote Sens 27(3):155-166

Boender CGE, de Graan JG, Lootsma FA (1989) Multi-criteria decision analysis with fuzzy pairwise comparisons. Fuzzy Sets Syst 29(2):133-143

Brahma AK (2018) A look on some applications of fuzzy VIKOR and fuzzy AHP methods on flood risk. Int J Appl Eng Res 13(18):13689-13696

Buckley JJ (1985) Fuzzy hierarchical analysis. Fuzzy Sets Syst 17(3):233-247

Chang DY (1996) Applications of the extent analysis method on fuzzy AHP. Eur J Oper Res 95(3):649-655

Chitsaz N, Malekian A (2016) Development of a risk-based multicriteria approach for watershed prioritization with consideration of soil erosion alleviation (case study of Iran). Environ Earth Sci. https://doi.org/10.1007/s12665-016-6256-3

Chopra R, Dhiman RD, Sharma PK (2005) Morphometric analysis of sub-watersheds in Gurdaspur district, Punjab using remote sensing and GIS techniques. J Indian Soc Remote Sens 33(4):531-539

Choudhari PP, Nigam GK, Singh SK, Thakur S (2018) Morphometric based prioritization of watershed for groundwater potential of Mula river basin, Maharashtra, India. Geol Ecol Landsc 2(4):256-267

Chowdary VM, Chakraborthy D, Jeyaram A, Murthy YK, Sharma JR, Dadhwal VK (2013) Multi-criteria decision making approach for watershed prioritization using analytic hierarchy process technique and GIS. Water Resour Manag 27(10):3555-3571

Chung ES, Hong WP, Lee KS, Burian SJ (2011) Integrated use of a continuous simulation model and multi-attribute decision-making for ranking urban watershed management alternatives. Water Resour Manag 25(2):641-659

Clarke JI (1966) Morphometric from maps, essays in geomorphology. Elsevier, New York, pp 235-274

Das S, Patel PP, Sengupta S (2016) Evaluation of different digital elevation models for analyzing drainage morphometric parameters in a mountainous terrain: a case study of the Supin-Upper Tons Basin, Indian Himalayas. SpringerPlus 5(1):1544

Dinpashoh Y, Singh VP, Biazar SM, Kavehkar S (2019) Impact of climate change on streamflow timing (case study: Guilan Province). Theoret Appl Climatol 138(1-2):65-76

Fang D, Hao L, Cao Z, Huang X, Qin M, Hu J, Sun G (2020) Combined effects of urbanization and climate change on watershed evapotranspiration at multiple spatial scales. J Hydrol 587:124869

Faniran A (1968) The index of drainage intensity-a provisional new drainage factor. Aust J Sci 31:328-330

Farhan Y, Anaba O (2016) A remote sensing and GIS approach for prioritization of Wadi Shueib Mini-Watersheds (Central Jordan) based on morphometric and Soil erosion susceptibility analysis. J Geogr Inf Syst 8(1):1-19

Farr T, Rosen PA, Caro E, Crippen R, Duren R, Hensley S (2007) The shuttle radar topography mission. Rev Geophys 45(2):16-17
Forkuor G, Maathuis B (2012) Chapter 9: Comparison of SRTM and ASTER derived digital elevation models over two regions in Ghana-implications for hydrological and environmental modeling. In: Piacentini T (ed) Studies on environmental and applied geomorphology. InTech, Rijeka, pp 219-240

Gautam PK, Singh DS, Kumar D, Singh AK (2020) A GIS-based approach in drainage morphometric analysis of Sai River Basin, Uttar Pradesh, India. J Geol Soc India 95:366-376

Gopinath G, Nair AG, Ambili GK, Swetha TV (2016) Watershed prioritization based on morphometric analysis coupled with multi criteria decision making. Arab J Geosci 9(2):129

Grohmann CH (2004) Morphometric analysis in geographic information systems: applications of free software GRASS and R. Comput Geosci 30(9-10):1055-1067

Hack JT (1957) Studies of longitudinal stream profiles in Virginia and Maryland, vol 294. US Government Printing Office, Washington, DC

Hadley RF, Schumm SA (1961) Sediment sources and drainage basin characteristics in upper Cheyenne River basin. US Geol Surv Water-Supply Pap 1531:198

Han WJ, Tsay WD (1998) Formulation of quality strategy using analytic hierarchy process. In: Twenty seven annual meeting of the western decision science institute, pp 580-583. University of Northern Colorado, USA

Hembram TK, Saha S (2020) Prioritization of sub-watersheds for soil erosion based on morphometric attributes using fuzzy AHP and compound factor in Jainti River basin, Jharkhand, Eastern India. Environ Dev Sustain 22(2):1241-1268

Horton RE (1932) Drainage-basin characteristics. Eos, Tran Criteria Geophys Union 13(1):350-361

Horton RE (1945) Erosional development of streams and their drainage basins; hydrophysical approach to quantitative morphology. Geol Soc Am Bull 56(3):275-370

Hungr O (2000) Analysis of debris flow surges using the theory of uniformly progressive flow. Earth Surf Process Landf 25:483-495

Islam A, Deb Barman S (2020) Correction to: drainage basin morphometry and evaluating its role on flood-inducing capacity of tributary basins of Mayurakshi River. India. SN Appl Sci. https:// doi.org/10.1007/s42452-020-2979-6

Jafarzadegan K, Merwade V (2017) A DEM-based approach for largescale floodplain mapping in ungauged watersheds. J Hydrol 550:650-662

Jain P, Ramsankaran RAAJ (2019) GIS-based integrated multi-criteria modelling framework for watershed prioritisation in India-a demonstration in Marol watershed. J Hydrol 578:124131

Jaiswal RK, Thomas T, Galkate RV, Ghosh NC, Singh S (2014) Watershed prioritization using Saaty's AHP based decision support for soil conservation measures. Water Resour Manag 28(2):475-494

Jaiswal RK, Ghosh NC, Lohani AK, Thomas T (2015) Fuzzy AHP based multi criteria decision support for watershed prioritization. Water Resour Manag 29(12):4205-4227

Kanth TA, Hassan Z (2012) Morphometric analysis and prioritization of watersheds for soil and water resource management in Wular catchment using geo-spatial tools. Int J Geol Earth Environ Sci 2(1):30-41

Kaushik P, Ghosh P (2015) 3D DEM delineation of Chambal river basin from SRTM data using remote sensing and GIS technology. Int J Remote Sens Geosci 4(4):1-6

Khan MA, Gupta VP, Moharana PC (2001) Watershed prioritization using remote sensing and geographical information system: a case study from Guhiya, India. J Arid Environ 49:465-475. https://doi. org/10.1006/jare.2001.0797

Kim Y, Chung ES, Jun SM, Kim SU (2013) Prioritizing the best sites for treated wastewater instream use in an urban watershed using fuzzy TOPSIS. Resour Conserv Recycl 73:23-32 
Kiran VSS, Srivastava YK (2012) Check dam construction by prioritization of micro watershed, using morphometric analysis as a perspective of remote sensing and GIS for Simlapal Block, Bankura, WB. Bonfring Int J Ind Eng Manag Sci 2:20-31

Koshak N, Dawod G (2011) A GIS morphometric analysis of hydrological catchments within Makkah Metropolitan area, Saudi Arabia. Int J Geomat Geosci 2(2):544-554

Kouli M, Vallianatos F, Soupios P, Alexakis D (2007) GIS-based morphometric analysis of two major watersheds, western Crete, Greece. J Environ Hydrol 15(1):1-17

Kumar B, Venkatesh M, Triphati A (2017) A GIS-based approach in drainage morphometric analysis of Rihand River Basin, Central India. Sustain Water Resour Manag 4(1):45-54. https://doi. org/10.1007/s40899-017-0118-3

Lapena DR, Martz LW (1996) An investigation of the spatial association between snow depth and topography in a Prairie agricultural landscape using digital terrain analysis. J Hydrol 184(3-4):277-298

Leopold LB, Wolman MG, Miller JP (1964) Fluvial processes in geomorphology. WH Freeman and Co., San Francisco

Magesh NS, Chandrasekar N, Soundranayagam JP (2011) Morphometric evaluation of Papanasam and Manimuthar watersheds, parts of Western Ghats, Tirunelveli district, Tamil Nadu, India: a GIS approach. Environ Earth Sci 64:373-381

Malczewski J (1999) GIS and multicriteria I analysis. Wiley, New York

Manu MS, Anirudhan S (2008) Drainage characteristics of Achankovil river basin, Kerala. J Geol Soc India 71(6):841

Maurya S, Srivastava PK, Gupta M, Islam T, Han D (2016) Integrating soil hydraulic parameter and microwave precipitation with morphometric analysis for watershed prioritization. Water Resour Manag 30(14):5385-5405

Meshram SG, Alvandi E, Singh VP, Meshram C (2019) Comparison of AHP and fuzzy AHP models for prioritization of watersheds. Soft Comput 23(24):13615-13625

Miller VC (1953) Quantitative geomorphic study of drainage basin characteristics in the Clinch Mountain area, Virginia and Tennessee. Technical report (Columbia University. Department of Geology); no. 3

Mishra C, Jaiswal R, Nema A, Chandola V, Chouksey A (2018) Priority assessment of sub-watershed based on optimum number of parameters using fuzzy-AHP decision support system in the environment of RS and GIS. J Indian Soc Remote Sens 47(4):603617. https://doi.org/10.1007/s12524-018-0904-x

Mohd I, Sajjad H (2014) Watershed prioritization using morphometric and land use/land cover parameters of Dudhganga catchment Kashmir Valley India using spatial technology. J Geophys Remote Sensing 3:115. https://doi.org/10.4172/2169-0049.1000115

Morisawa ME (1959) Relation of morphometric properties to run off in the Little Mill Creek, Ohio drainage basin, (Columbia University, Department of Geology). Technical Report, 17, Office of Naval Research, Project N. R, 389-042

Morisawa M (1985) Rivers: form and process. Geomorphol Texts $7: 220-222$

Nag SK, Chakraborty S (2003) Influence of rock types and structures in the development of drainage network in hard rock area. J Indian Soc Remote Sens 31(1):25-35

Obi Reddy GE, Maji AK, Gajbhiye KS (2002) GIS for morphometricanalysis of drainage basins. GIS India 4(11):9-14

Pandey PC, Sharma LK, Nathawat MS (2012) Geospatial strategy for sustainable management of municipal solid waste for growing urban environment. Environ Monit Assess 184:2419-2431

Patel A, Katiyar KS, Prasad V (2016) Performances evaluation of different open source DEM using diferential global positioning system (DGPS). Egypt J Remote Sens Space Sci 19(1):7-16

Prabhakar A, Singh K, Lohani A, Chandniha S (2019) Study of Champua watershed for management of resources by using morphometric analysis and satellite imagery. Appl Water Sci. https://doi.org/10.1007/s13201-019-1003

Prakash K, Rawat D, Singh S, Chaubey K, Kanhaiya S, Mohanty T (2019) Morphometric analysis using SRTM and GIS in synergy with depiction: a case study of the Karmanasa River basin. Appl Water Sci, North central India. https://doi.org/10.1007/s1320 1-018-0887-3

Putty MRY (2007) Quantitative geomorphology of the upper Kaveri basin in Western Ghat, in Karnataka. IE (I). J CV 88:44-49

Rahaman S, Ajeez S, Aruchamy S, Jegankumar R (2015) Prioritization of sub watershed based on morphometric characteristics using fuzzy analytical hierarchy process and geographical information system - a study of Kallar watershed, Tamil Nadu. Aquat Procedia 4(1):1322-1330. https://doi.org/10.1016/j.aqpro .2015 .02 .172

Rahmati O, Haghizadeh A, Stefanidis S (2016) Assessing the accuracy of GIS-based analytical hierarchy process for watershed prioritization; Gorganrood River Basin, Iran. Water Resour Manag 30(3):1131-1150

Rai PK, Mohan K, Mishra S, Ahmad A, Mishra VN (2017) A GIS based approach in drainage morphometric analysis of Kanhar River Basin India. Appl Water Sci 7(1):217-232

Ratnam NK, Srivastava YK, Rao VV, Amminedu E, Murthy KSR (2005) Check dam positioning by prioritization micro-watersheds using SYI model and morphometric analysis-remote sensing and GIS perspective. J Indian Soc Remote Sens 33(1):25-38

Roy S, Sahu AS (2016a) Effectiveness of basin morphometry, remote sensing, and applied geosciences on groundwater recharge potential mapping: a comparative study within a small watershed. Front Earth Sci 10(2):274-291

Roy S, Sahu AS (2016b) Morphotectonic map generation using geoinformatics technology: case study over the Ajay-Damodar Interfluve, West Bengal, India. Arab J Geosci 9(3):183

Rudraiah M, Govindaiah S, Srinivas VS (2008) Morphometry using remote sensing and GIS techniques in the sub-basins of Kagna river basin, Gulburga district, Karnataka, India. J Indian Soc Remote Sens 36:351-360

Saaty TL (1980) Fundamentals of decision making and priority theory with analytical hierarchical process, vol 4. RWS Publications University of Pittsburgh, Pittusburgh, pp 3-95

Sangma F, Guru B (2020) Watersheds characteristics and prioritization using morphometric parameters and fuzzy analytical hierarchal process (FAHP): a part of lower Subansiri Sub-Basin. J Indian Soc Remote Sens 48(3):473-496. https://doi.org/10.1007/s1252 4-019-01091-6

Schumm SA (1956) Evolution of drainage systems and slopes in badlands at Perth Amboy, New Jersey. Geol Soc Am Bull 67(5):597-646

Sen PK (1993) Geomorphological analysis of drainage basins. The University of Burdwan, Bardhaman, pp 32-38

Sharma A, Tiwari KN (2014) A comparative appraisal of hydrological behavior of SRTM DEM at catchment level. J Hydrol 519:1394-1404

Singh P, Thakur JK, Singh UC (2013) Morphometric analysis of Morar River Basin, Madhya Pradesh, India, using remote sensing and GIS techniques. Environ Earth Sci 68:1967-1977

Sinha J, Jha S, Goyal MK (2019) Influences of watershed characteristics on long-term annual and intra-annual water balances over India. J Hydrol 577:123970

Smith KG (1950) Standards for grading texture of erosional topography. Am J Sci 248:655-668

Sreedevi PD, Owais SHHK, Khan HH, Ahmed S (2009) Morphometric analysis of a watershed of South India using SRTM data and GIS. J Geol Soc India 73(4):543-552 
Srivastava RK, Sharma HC (2012) Prioritization of mini watersheds in Badri Gad watershed using GIS technique. J Soil Water Conserv 11(3):218-226

Strahler AN (1952) Hypsometric (area-altitude) analysis of erosional topography. Geol Soc Am Bull 63(11):1117-1142

Strahler AN (1957) Quantitative analysis of watershed geomorphology. Trans Am Geophys Union 38:913-920

Strahler A (1964) Quantitative geomorphology of drainage basins and channel networks. In: Chow V (ed) Handbook of applied hydrology. McGraw Hill, New York, pp 439-476

Suresh M, Sudhakar S, Tiwari KN, Chowdary VM (2004) Prioritization of watersheds using morphometric parameters and assessment of surface water potential using remote sensing. J Indian Soc Remote Sens 32:249-259

Svetlitchnyi AA, Plotnitskiy SV, Stepovaya OY (2003) Spatial distribution of soil moisture content within catchments and its modelling on the basis of topographic data. J Hydrol 277(1-2):50-60

Thakur J, Srivastava PK, Singh S, Vekerdy Z (2012) Ecological monitoring of wetlands in semi-arid region of Konya closed Basin. Turkey. Reg Environ Change 12(1):133-144. https://doi.org/10.1007/ s10113-011-0241

Thomas J, Joseph S, Thrivikramji KP, Abe G, Kannan N (2012) Morphometrical analysis of two tropical mountain river basins of contrasting environmental settings, the southern Western Ghats, India. Environ Earth Sci 66:2353-2366

Triantaphyllou E, Mann SH (1995) Using the analytic hierarchy process for decision making in engineering applications: some challenges. Int J Ind Eng Appl Pract 2(1):35-44

Tripathi S, Sayre K, Kaul J, Narang R (2003) Growth and morphology of spring wheat (Triticum aestivum L.) culms and their association with lodging: effects of genotypes, $\mathrm{N}$ levels and ethephon. Field Crops Res 84(3):271-290. https://doi.org/10.1016/s0378 $-4290(03) 00095$

Van Laarhoven PJM, Pedrycz W (1983) A fuzzy extension of Saaty's priority theory. Fuzzy Sets Syst 11:229-241

Vijith H, Satheesh R (2006) GIS based morphometric analysis of two major upland sub-watersheds of Meenachil river in Kerala. J Indian Soc Remote Sens 34(2): 181

Zadeh LA (1965) Fuzzy sets. Inf Control 8(3):338-353

Publisher's Note Springer Nature remains neutral with regard to jurisdictional claims in published maps and institutional affiliations. 